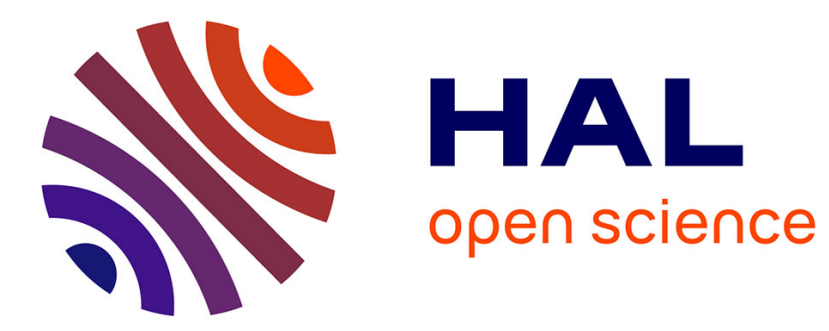

\title{
Current Status of Antisense Oligonucleotide-Based Therapy in Neuromuscular Disorders
}

Flavien Bizot, Adeline Vulin, Aurélie Goyenvalle

\section{To cite this version:}

Flavien Bizot, Adeline Vulin, Aurélie Goyenvalle. Current Status of Antisense Oligonucleotide-Based Therapy in Neuromuscular Disorders. Drugs, In press, 10.1007/s40265-020-01363-3 . hal-02912701

\section{HAL Id: hal-02912701 \\ https://hal.science/hal-02912701}

Submitted on 6 Aug 2020

HAL is a multi-disciplinary open access archive for the deposit and dissemination of scientific research documents, whether they are published or not. The documents may come from teaching and research institutions in France or abroad, or from public or private research centers.
L'archive ouverte pluridisciplinaire HAL, est destinée au dépôt et à la diffusion de documents scientifiques de niveau recherche, publiés ou non, émanant des établissements d'enseignement et de recherche français ou étrangers, des laboratoires publics ou privés. 
3 政

Flavien Bizot ${ }^{1}$, Adeline Vulin ${ }^{1,2}$ and Aurélie Goyenvalle ${ }^{1,3 \S}$

${ }^{1}$ Université Paris-Saclay, UVSQ, Inserm, END-ICAP, 78000 Versailles, France.

${ }^{2}$ SQY Therapeutics, Université de Versailles St-Quentin, Montigny le bretonneux, France.

${ }^{3}$ LIA BAHN, Centre scientifique de Monaco, Monaco.

${ }^{\S}$ Correspondence to: aurelie.goyenvalle@uvsq.fr

Short title: Antisense oligonucleotide-based therapies

\section{Key points:}

ASO hold great promise as a therapeutic platform for the treatment of neuromuscular disorders.

The clinical benefit of ASO-therapy still highly depends on the target tissue and route of administration.

Development of more potent chemistries or novel delivery systems is still required to improve targeted delivery to muscles.

8 This is a pre-print of an article published in Drugs. The final authenticated version is available online at: https://doi.org/10.1007/s40265-020-01363-3 
2 ABSTRACT

3 Neuromuscular disorders include a wide-range of diseases affecting the peripheral nervous system,

4 which are primarily characterized by progressive muscle weakness and wasting. While there were no

5 effective therapies until recently, several therapeutic approaches have advanced to clinical trials in

6 the past few years. Among these, the antisense technology aiming at modifying RNA processing and

7 function has remarkably progressed and a few antisense oligonucleotides (ASO) have now been

8 approved. Despite these recent clinical successes, several ASO have also failed and clinical programs

9 have been suspended, in most cases when the route of administration was systemic, highlighting the existing challenges notably with respect to effective ASO delivery.

In this review we will summarize the recent advances and current status of antisense basedtherapies for neuromuscular disorders, using successful as well as unsuccessful examples to highlight the variability of outcomes depending on the target tissue and route of administration. We will describe the different ASO-mediated therapeutic approaches, including splice switching applications, steric blocking strategies and targeted gene knock-down mediated by ribonuclease $\mathrm{H}$ recruitment. Throughout this overview, we will discuss the merits and challenges of the current ASO technology,

17 and discuss the future of ASO development. 


\section{INTRODUCTION}

Antisense oligonucleotide (ASO)-based therapeutics have made tremendous progress in the last 20 years and the recent approval of several drugs have increased the interest in the field even more.

ASOs are typically synthetic single stranded oligonucleotides of 12 to 30 nucleotides long ${ }^{1-3}$, designed to bind to a messenger RNA (mRNA) or non-coding RNA through Watson-Crick base pairing in order to modulate their function/expression. ASOs were first used in 1978 by Zamecnik and Stephenson as a gene silencing approach ${ }^{4}$, but the technology has rapidly evolved since then with numerous other possible applications making them a valuable tool for genetic-based therapeutics ${ }^{5}$. While the first unmodified ASOs composed of a phosphodiester backbone and sugar rings were rapidly degraded within cells and bloodstream ${ }^{6}$, various modifications have progressively been introduced in their chemical structure in order to protect them from nuclease activity and increase their stability and affinity to target RNA ${ }^{7}$. One of the first modifications introduced was the replacement of one of nonbridging oxygen atoms in the phosphate group with a sulfur atom resulting in phosphorothioate (PS) ASO. This substitution increases the resistance to nuclease degradation and still supports ribonuclease $\mathrm{H}$ (RNase $\mathrm{H}$ ) activity to degrade the target mRNA or mutant toxic mRNA. In addition to their endogenous nuclease resistance, PS modifications offer a significant advantage in terms of pharmacokinetics. Their enhanced affinity for numerous proteins, including plasma, cell surface and intracellular proteins ${ }^{8,9}$ facilitates distribution and cellular uptake of PS-ASOs compared to their phosphodiester (PO) counterparts. However, PS modifications are also known to cause undesirable effects due to plasma protein binding ${ }^{10}$, raising questions for their safety in humans ${ }^{11}$. Acute reactions of PS backbones may include immune-cell activation ${ }^{12}$, complement activation ${ }^{13}$ or prolongation of coagulation times ${ }^{14,15}$; known to be transient and normalize when ASOs are cleared from the bloodstream. Despite these safety concerns, PS backbones remain one of the most largely used chemical modifications to protect ASOs from nuclease activity and increase their stability ${ }^{16}$.

To further improve nuclease resistance and RNA binding affinity, second generation ASOs were developed with introduction of a chemical modification in the 2'-position of the sugar moiety such as 
1 2'O-methyl (2'OMe), 2'O-methoxyethyl (2'MOE), 2'-fluorinated (2'F) and 2'-O-aminopropyl analogs ${ }^{17}$.

2 Interestingly 2'-modified ASOs were reported to reduce immune stimulation side effects compared

3 to PS-modified $\mathrm{ASO}^{18}$. Chemical ASO modifications have kept evolving with substantial changes in

4 the sugar and have led to a wide variety of designs such as morpholinos ${ }^{19}$, locked nucleic acids

$5 \quad(\text { LNAs })^{20}, 2^{\prime}-4^{\prime}$-constrained ethyl $(\mathrm{CEt})^{21}$ or peptide nucleic acids (PNAs) ${ }^{22}$.

6

7 ASOs can interfere and modulate RNA function via multiple mechanisms which will impact their

design and chemical modifications. Several reviews have previously detailed the various molecular mechanisms through which an ASO can impact gene expression ${ }^{23-25}$. Briefly, ASOs can be used to promote RNA degradation via the recruitment of RNase $\mathrm{H} 1$ which will cleave the mRNA-ASO heteroduplex while leaving the ASO intact (figure 1, left panel). It is important to note that most sugar modified ASOs became unable to elicit RNase H1-mediated RNA degradation, hence ASOs must be designed as "gapmers" with a central core of 8 to 10 consecutive DNA nucleotides to support binding and cleavage by RNase H1. Alternatively, ASOs can be fully modified and work through steric hindrance mechanisms either to modulate splicing (in which case they may be called splice switching oligomer - SSO), inhibit RNA toxicity through the disruption of RNA structure, impact polyadenylation selection site, inhibit translation, or bind to microRNAs to block their interaction with mRNA (figure 1, right panel). The variety of mechanisms through which ASO can act and the subsequent therapeutic applications truly represent unique opportunities for the treatment of many conditions. Steady progress in chemistry and design over the years have led to several approved ASO and numerous others currently being tested in clinical trials, in particular for neuromuscular diseases. These recent successes elicit optimism and hope for the development of future therapeutics using the antisense technology. However, the clinical benefit of ASO therapy still very much depends on the target tissue and route of administration. The therapeutic potential of systemically delivered ASOs remains far behind since it is assumed that only about $1 \%$ of ASO reach the correct cellular compartment after intravenous or subcutaneous administration ${ }^{26}$. In this review, we will discuss the 
recent advances and current status of ASO therapies for several neuromuscular disorders including Duchenne muscular dystrophy (DMD), spinal muscular atrophy (SMA), myotonic dystrophy (DM1), amyotrophic lateral sclerosis (ALS) and Huntington disease (HD). Through these examples, we will cover the broad range of neuromuscular disorders from the muscle to the more neurodegenerative end of the spectrum, like ALS and HD, to reflect the variation in clinical benefit depending on the target tissue/route of administration, but also with respect to the diversity of chemistries and mechanisms of action.

\section{Duchenne muscular dystrophy}

With an incidence of one per 5,000 boys on average ${ }^{27}$, Duchenne muscular dystrophy is the most common muscular dystrophy. DMD is caused by mutations, typically large deletions (approximately $65 \%)$ in the DMD gene, disrupting the open reading frame and leading to non-functional or absent dystrophin protein. As dystrophin plays a major mechanical and signalling link between the actin cytoskeleton and the extracellular matrix, its absence leads to progressive muscle wasting and premature death of patients. In contrast to the frame shifting mutations observed in DMD, mutations maintaining an open reading frame allow the production of a partially deleted but, in most cases, functional dystrophin. This is observed in the milder phenotype, Becker muscular dystrophy (BMD), which results in a later age of onset and milder clinical involvement (ranging from intermediate to asymptomatic). Moreover, about 50\% of DMD patients have individual dystrophin-positive muscle fibers ${ }^{28}$, called revertant fibers, with protein correctly localized at the membrane. It has been shown that they come from a spontaneous skipping of several exons allowing to restore an in-frame transcript ${ }^{29}$. Altogether these observations led to the emergence of a novel therapeutic approach named exon-skipping using ASO to modulate the pre-mRNA splicing (figure 1, right panel). The principle to restore an opening reading frame by exon-skipping therapy for DMD has first been demonstrated more than twenty years ago in culture cells ${ }^{29}$. Since, numerous in vivo studies performed in several animal models have provided pre-clinical evidence for the therapeutic potential 
1

2

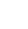

of antisense strategy. Although the exon-skipping approach appears to be able to restore the reading frame in a large proportion of patients (possibly up to $83 \%$ of all DMD patients ${ }^{32}$ ), this strategy will not offer a definite cure but an improvement towards a BMD-like phenotype depending on the functionality of the restored dystrophin, as not all protein domains are dispensable. Favorably, the majority of deletions clusters into hotspot regions between exons 43 and 53, suggesting that skipping of the same group of exons is applicable to large groups of patients. Notably, exon 51 skipping (applicable to $13 \%$ of all patients) was the primary choice for numerous phase 1 clinical trials, which evaluated various chemistries of antisense oligonucleotides as detailed below.

\subsection{2'-O-Methyl-PS RNA.}

While most of the preclinical work using 2'OMe-PS ASO for DMD was produced by the LUMC (Leiden University Medical Center)-based research groups, first clinical data were actually published by a Japanese group in 2006 using a PS DNA ASO (Table 1). A single patient, with an exon 20 deletion, was injected with a 31-mer ASO targeting the exon 19 of the DMD gene (named AO19) in the peripheral vein at $0.5 \mathrm{mg} / \mathrm{kg}$ four times at one-week intervals ${ }^{33}$. The treatment was well tolerated and resulted in the detection of skipped transcript in lymphocytes (despite this target being questionable), and traces in biopsied biceps muscle. Nevertheless, the novel transcript did not allow the restoration of quantifiable dystrophin expression and no follow-up studies were ever conducted.

In parallel in Europe, a 20-mer 2'OMe-PS ASO targeting exon 51 was developed and shown to restore significant levels of dystrophin in mouse models of $\mathrm{DMD}^{34}$. Based on these encouraging preclinical data, the Dutch group in collaboration with Prosensa evaluated the intramuscular injection of this ASO named drisapersen in four DMD patients eligible for exon 51 skipping $^{35}$. The treatment was well tolerated and confirmed the proof of principle of the ASO-mediated exon skipping approach for DMD since some dystrophin expression was detected, supporting the development of further clinical investigations. Results of the phase $1 / 2$ a trial evaluating the systemic administration of drisapersen were published in $2011^{36}$. Four groups of 3 DMD boys received abdominal subcutaneous injection at 
doses of $0.5,2,4$ and $6 \mathrm{mg} / \mathrm{kg} /$ week of 2'OMe-PS ASO for 5 weeks followed by a 6 to 15 months offtreatment and a 12-week extension phase at $6 \mathrm{mg} / \mathrm{kg} /$ week. While no serious adverse effects were reported, a total of 120 mild or moderate adverse events occurred, notably proteinuria and several types of reactions at the injection site. Tibialis anterior muscle biopsy samples were analyzed at 2 weeks and 7 weeks after the end of the dose-escalation phase. Exon 51 skipping was observed in all patients receiving 2, 4 or $6 \mathrm{mg} / \mathrm{kg} /$ week at both time points but with variable extent. Quantification of western blot shows that dystrophin signal intensity was 1.5 to 8.2 times greater than the baseline condition (taken from $0.5 \mathrm{mg} / \mathrm{kg}$ group of patients) in the groups receiving 4 and $6 \mathrm{mg} / \mathrm{kg} / \mathrm{week}, 2$ weeks after the end of the treatment. Following 12 weeks of treatment, no increase in specific muscle force was observed but there was average improvement of $35.2 \pm 28.7 \mathrm{~m}$ in the distance walked in 6 minutes (6MWD). Those 12 patients entered a long-term 188-week extension study with subcutaneous injection of $6 \mathrm{mg} / \mathrm{kg} /$ week initially ${ }^{37}$. Similar adverse effects were reported, including injection-site reactions (erythema, hematoma, and induration), increased urinary a1-microglobulin, and proteinuria. Biopsies were taken from the tibialis anterior muscle at week 24 for all subjects and at either week 68 or 72 for volunteering subjects. Although exon-skipping and dystrophin were detected at both time-points, no formal conclusion could be drawn on potential increase from baseline because no material from pre-treatment biopsies was available. At the end of the treatment, 2 patients were non-ambulant and 2 were unable to complete the 6MWD at later visits. Nevertheless, on the 8 remaining subjects, the 6MWD appeared improved by a median increase of 64 meters (mean=33) and the cardiac function showed stability but on the other hand, muscle strength decreased during the study. Interestingly though, despite the heterogeneity of subjects, some of them who were in a decline stage of the disease maintained ambulation throughout the study. Based on these relatively encouraging data, an open-label extension phase 3 study was launched with 186 ambulant subjects ${ }^{38}$. Unfortunately, the slight difference observed in the 6MWD from baseline was found non-significant, which was thought to be largely due to subgroup heterogeneity. A post-hoc analysis, performed on a subgroup of 80 subjects with a baseline 6MWD 
1

2

3

4

between 300 and 400 meters, revealed a treatment benefit in 6MWD of 35.4 meters (95\% Cl: 1.8, 69.0), supporting early intervention. The inability to meet the primary efficacy endpoint (improvement in 6MWD) together with the significant adverse effects (injection-site reactions and renal issues) led to the rejection of drisapersen's application by the US Food and drugs Administration (FDA). By mid-2016, Biomarin announced the withdrawal of drisapersen market authorization application in Europe and the discontinuation of all their ASO programs for DMD which included exons 44, 45 and 53 to invest in research of next generation ASOs.

\subsection{Phosphorodiamidate Morpholino Oligomer (PMO)}

In parallel to the 2'OMe-PS ASO development, another chemistry of ASO was developed for DMD: Phosphorodiamidate Morpholino Oligomers also called PMO. Following numerous preclinical studies showing encouraging results ${ }^{39}$, the UK MDEX consortium conducted a phase $1 / 2$ trial with a 30-mer PMO targeting exon 51, named eteplirsen, in seven patients. Intramuscular injection of eteplirsen was well tolerated by all patients and intensity of dystrophin staining increased to $42 \%$ of normal levels in dystrophin positive fibers of patients treated with the higher dose ${ }^{40}$. While intramuscular injection was a valuable proof-of-concept, the main challenge in DMD is to target cardiac and respiratory muscles therefore systemic delivery was next assessed. Sarepta started a dose escalation study from 0.5 to $20 \mathrm{mg} / \mathrm{kg}$ with multiple injections ${ }^{41}$. Adverse events were generally mild to moderate and a dose-dependent significant increase in dystrophin expression was observed and associated with $\alpha$-sarcoglycan and neuronal nitric oxide ( $\mathrm{nNOS}$ ) restoration at the sarcolemma. Following these encouraging results, phase 2 studies with higher doses (30 and $50 \mathrm{mg} / \mathrm{kg}$ ) were launched $^{42}$. Eteplirsen injections resulted in increased dystrophin production in all patients following at least 24 weeks of treatment with a statistically significant difference in the 6MWD in some patients, depending on the age-related disease progression ${ }^{43}$. Based on detection of dystrophin protein (although minor) and the absence of adverse events, eteplirsen was approved by the FDA in 2016, under the accelerated approval pathway, despite no measures of muscle function. Although its 
1

2

approval was shrouded in controversy, eteplirsen became the first approved drug for DMD in the US, as well as the first approved splice-switching $\mathrm{ASO}^{44}$. Sarepta was asked to perform confirmatory studies to establish a clinical benefit which had not been demonstrated. In 2019, they started to recruit patients for a phase 3 study with intravenous (IV) injections of two different high doses (>30 $\mathrm{mg} / \mathrm{kg}$ ). In the meantime, they reported functional data from two non-ambulatory patients compared to 10 patients who remained ambulatory ${ }^{45}$ and showed that despite the loss of ambulation, their cardiac, pulmonary and upper limb functions remained relatively stable and the increase in dystrophin production (less than $2 \%$ ) was similar to those of ambulatory patients. As eteplirsen was well tolerated over 3.2 years, Sarepta performed a phase 3 study with 7 to 16 years old patients and a phase 2 study on younger child (4-6 years old), but no results have been published yet.

Regardless of eteplirsen's approval by the FDA in 2016, two years later the European Medicines Agency (EMA) gave a negative opinion for this treatment ${ }^{44}$. In their public report, the Committee for Medicinal Products for Human Use (CHMP) considered that the safety profile of eteplirsen had not been thoroughly characterized and they mentioned that a sufficient number of patients compared to placebo would be needed to conclude. They concluded that the current benefit-risk balance was not positive since the efficacy was not sufficiently demonstrated. This difference between the two agencies highlights their dissimilar views on the role of dystrophin as a surrogate endpoint. Despite this setback in Europe, Sarepta continued the clinical development of their PMO-ASOs notably targeting exons 45 and 53. Toxicology results in non-human primates suggested an encouraging safety profile of these two PMOs, SRP-4045 (Casimersen) and SRP-4053 (Golodirsen), similar to eteplirsen ${ }^{46}$. Findings were mostly limited to the kidneys, which presented minor microscopic changes that were non-adverse after 12 weeks of infusion with SRP-4045 and SRP-4053, or 39 weeks of infusion with eteplirsen at various doses $(5,40 \text { and } 320 \mathrm{mg} / \mathrm{kg} / \text { week })^{46}$. Based on positive results from a phase $1 / 2$ clinical trial ${ }^{47}$, golodirsen received in December 2019 its first global approval in the USA for the treatment of DMD patients amenable to exon 53 skipping ${ }^{48}$. 
2 Another company, NS-Pharma, in collaboration with Japanese groups, used another optimized sequence named Viltolarsen (NS-065/NCNP-01) to target exon 53 but with much higher doses (up to $80 \mathrm{mg} / \mathrm{kg}$ ). In a phase 1 dose-escalation trial, the increase of dystrophin was negligible, except for one patient with a dystrophin/spectrin ratio increased by $8.1 \%$, correlated to a significant skipping in the higher dose group ${ }^{49}$. No serious adverse events were reported and the observed drug reactions were common for ASOs such as proteinuria, albuminuria or increase in $\mathrm{N}$-acetyl- $\beta$-D-glucosaminidase but also anemia. Following this phase 1, parallel trials in USA/Canada and in Japan have been completed. During the Japanese phase $1 / 2$ study with the higher doses of 40 and $80 \mathrm{mg} / \mathrm{kg} /$ week for 24 weeks, the increase of dystrophin expression was between 0.13 and $2.78 \%$ respectively. In parallel, the North American phase 2 study with the same doses showed that the average increase in dystrophin protein was about $5 \%$ from baseline $e^{50}$. However, it is important to note that there are no standardized methodologies for dystrophin quantification between those studies, despite the recent emergence of alternative methods to quantify dystrophin, such as mass spectrometry, capillary western immunoassay or immune-affinity liquid chromatography ${ }^{51}$. Based on the presence of dystrophin restoration (without measurement of muscle function), and the absence of serious adverse effects Viltolarsen was approved in March 2020 and thus became the first ASO to be approved by the Japanese agency.

In spite of these recent approvals suggesting some success, the levels of restored dystrophin in biopsies from DMD patients treated with these compounds remain extremely low. It is therefore unclear at the moment whether these drugs can truly achieve clinically relevant outcomes. To improve the delivery of ASOs to targeted tissues ${ }^{26}$, alternative chemistries are being developed, as well as novel generations of conjugated ASOs. 


\subsection{Alternative chemistries and next generations of compounds}

Wave Life Sciences recently developed an investigational stereopure ASO (suvodirsen), designed for exon 51 skipping, which was shown to induce enhanced exon skipping and dystrophin protein restoration in cell cultures compared with other exon-skipping compounds such as eteplirsen or drisapersen (52\% dystrophin protein restoration in cells versus $1 \%$ with other exon skipping ASOs). A phase 1 clinical trial was initiated in November 2017 to assess the safety and tolerability of suvodirsen with 5 ascending doses, from 0.5 to $10 \mathrm{mg} / \mathrm{kg} /$ week. They reported infusion-associated reactions consisting of pyrexia, headache, vomiting and tachycardia, essentially for the doses equal or higher than $5 \mathrm{mg} / \mathrm{kg}$. As patients who received 7 or $10 \mathrm{mg} / \mathrm{kg}$ met the predefined stopping criteria, the remained patients moved directly into the open label extension at the $5 \mathrm{mg} / \mathrm{kg}$ dose level $\mathrm{I}^{52} . \mathrm{In}$ December 2019, Wave announced that interim results showed no change from baseline in dystrophin expression with either the 3.5 or $5 \mathrm{mg} / \mathrm{kg}$ doses of suvodirsen. Both the extension trial and the phase $2 / 3$ trial were discontinued and further development of exon 53 compounds was suspended.

Among advancing chemistries, a Japanese group developed a 2'-OMe RNA/ENA (2'-O,4'-C-ethylenebridged nucleic acid) chimera ASO to induce dystrophin exon 45 skipping $^{54}$. During the congress Myology in 2016, the group presented results from one clinical study with a 7-year old boy. After 4 weeks IV infusion at $0.5 \mathrm{mg} / \mathrm{kg} /$ week, they showed partial exon skipping and reported an increase of the 6MWD. A phase $1 / 2$ clinical trial is ongoing in Japan to evaluate the safety, tolerability, effectiveness, and pharmacokinetics of the drug (DS-5141). DMD patients are given subcutaneous injections of DS-5141 at different doses $(0.1,0.5,2$ and $6 \mathrm{mg} / \mathrm{kg})$ for up to 12 weeks and then enrolled in an extension protocol of 48 weeks with doses at 2 and $6 \mathrm{mg} / \mathrm{kg}$. Results announced in April 2018 by the company revealed no serious adverse events but efficacy data were unclear with detection of exon 45 skipping in all participants while dystrophin protein was only partially 
1 identified ${ }^{55}$. The study has been updated on the US Clinical Trials website and announced a study completion date in December 2020.

3

4 Conjugation of ASO to cell penetrating peptides (CPP) has also been investigated to improve delivery to the muscle and peptide conjugated-PMO (PPMO) have shown encouraging preclinical data ${ }^{56}$. Despite the toxicity issues arisen in non-human primates treated with the first PPMO developed against exon $50{ }^{57}$, newer generations of CPP with better safety profile have since been developed. Sarepta has recently completed a phase 1 trial with a PPMO targeting exon 51 and is now recruiting for a phase $1 / 2$. No results have been posted or published yet.

Development of other alternative chemistries led to the identification of tricyclo-DNA (tcDNA) as a promising ASO for therapeutic splice-switching applications. TCDNA have demonstrated unique pharmaceutical properties and widespread uptake in many tissues after systemic delivery; including the capacity to cross the blood brain barrier (BBB) at low level after systemic delivery ${ }^{58,59}$. A phase $1 / 2$ clinical trial is programmed for mid-2021.

Another alternative to overcome the delivery and potential toxicity challenges of ASO is the use of viral vectors encoding small nuclear RNAs engineered to shuttle antisense sequences into cells. This type of vectorization in adeno-associated virus (AAV) vector has demonstrated promising preclinical data in mouse and dog models of DMD, allowing appropriate subcellular localization with pre-mRNAs and long term correction ${ }^{60-62}$. Based on these encouraging findings, a phase $1 / 2$ clinical trial is currently being planned by Audentes therapeutics in collaboration with the Nationwide Children's Hospital to develop a first product candidate, AT702 targeting exon 2. Exon duplications account for $11 \%$ of DMD mutations and exon 2 is the most common duplication in patients. Targeting duplications aims to create a full-length dystrophin (i.e. fully functional) in contrast with internally deleted dystrophin resulting from the correction of frameshift or nonsense mutations. 


\section{Spinal muscular atrophy}

Spinal muscular atrophy (SMA) is a group of autosomal-recessive inherited disease characterized by progressive muscle atrophy due to the degeneration of $\alpha$-motor neurons of the anterior horn of spinal cord. In most cases SMA is caused by homozygous deletions of the gene SMN1 (survival motor neuron 1) encoding the SMN protein and its clinical phenotype is heterogeneous, ranging from a severe to a mild phenotype (SMA type 1 to 4). A prevalence of approximately $1-2$ per 100,000 persons and incidence around 1 in 10,000 live births have been estimated with SMA type 1 accounting for around $60 \%$ of all cases ${ }^{63}$. Loss of SMN leads to a progressive proximal muscle weakness and deleterious effects on respiratory function. In humans, the severity of the disease is mostly counterbalanced by the presence of the SMN2 gene and inversely proportional to its copy number but discrepant SMA cases support the role of other phenotype modifiers ${ }^{64}$. SMN2 differs from SMN1 by one nucleotide in the coding sequence: a C-T substitution at position 6 of exon 7 which results in its exclusion during the splicing of the pre-mRNA in about $90 \%$ of the transcripts, but with cells and tissues variation. This alternative spliced product lacking exon 7 is translated into a truncated protein that is degraded shortly after while the $10 \%$ correct transcript translates for a fulllength functional SMN protein.

Considering that SMN2 gene is similar in all SMA patients and that they usually have several copies of SMN2, modulating its splicing has become an attractive therapeutic option. The mechanism of splicing regulation is complex and involves more than 40 regulatory protein factors. Splicing of SMN2 exon 7 requires many different elements, including a suboptimal intron 6 branch point ${ }^{65}$, an extended inhibitory context, a conserved tract domain, an inhibitory $3^{\prime}$-cluster, an intronic silencer element in intron 7 (ISS-N1) and a terminal stem-loop (TSL) structure on the $5^{\prime}$ splice site of exon $7^{66}$. Once the genomic organization of SMN2 was better characterized, research groups started using the antisense platform in order to force the inclusion of exon 7 (figure 1, right panel). 
1

2

Various classes of ASOs have been developed to modulate SMN2 mRNA splicing, including 2'OMe-PS, PMO and 2'MOE-PS. The most promising candidate identified was an 18-mer 2'MOE-PS ASO targeting the ISS-N1 sequence which was reported to regulate SMN2 exon 7 inclusion ${ }^{67}$. Initial studies using this ISS-N1 ASO in a mild SMA mouse model (type 3) demonstrated rescue of tail and ear necrosis following intracerebroventricular (ICV) infusion ${ }^{68}$. A year later, the same group demonstrated increased survival of type 1 SMA mice after subcutaneous injections at postnatal day $\mathrm{PO}$ and $\mathrm{P}^{69}$. Clinical trials were initiated in 2012 with this oligonucleotide, named nusinersen (originally IONIS-SMNRx) by lonis Pharmaceuticals. The first phase 1 clinical trial was conducted in patients with type 2 and $3 \mathrm{SMA}^{70}$ and was aimed at evaluating safety, tolerability and pharmacokinetics of a single intrathecal injection at different doses $(1,3,6$ and $9 \mathrm{mg})$. In this study, nusinersen was not only well tolerated but an improvement of motor function was observed with the $9 \mathrm{mg}$ dose. Moreover, with a half-life in cerebrospinal fluid (CSF) of 4 to 6 months, nusinersen allows large intervals between injections. Several clinical studies quickly followed these encouraging results. First, a phase 2 evaluating multi intrathecal doses of 6 to $12 \mathrm{mg}$ over 32 months of treatment was launched in infants with early onset ${ }^{71}$. The treatment was well tolerated and patients in the $12 \mathrm{mg}$ group showed improvement in motor function and an increase in electrically excitable muscle. Moreover, these patients surpassed median age of death, compared to natural history cohorts. Following these favorable results, a phase 3 study was also initiated with more injections in the first months. Since a greater improvement was seen in patient with a shorter disease progression during treatment initiation, the crucial question of a better clinical response with a pre-symptomatic treatment has been examined in a phase 2 study. Interim efficacy and safety results were recently published $^{72}$ and reported that all injected patients past the age of symptom onset were alive, without permanent ventilation. They achieved motor milestones and are continuing to make progress, highlighting the need to start treatment before symptomatic period. 
1

2

In parallel to these trials on type 1 and 2 patients, studies were conducted on patients with lateronset SMA, including a phase 3 study in children over the course of 15 months ${ }^{73}$ and a phase $1 \mathrm{~b} / 2 \mathrm{a}$ followed by a 3-year extension study ${ }^{74}$. They both confirmed the improvement of motor function and reported that none of the adverse effect was considered drug related therefore validating the effectiveness of nusinersen. In the extension study, electrophysiological outcome measures were reported stable suggesting that the benefit of treatment on distal innervation capacity may be less robust than the overall benefit on motor function. The authors suggested that this may be influenced by different factors such as age, severity of denervation at the time of enrollment, duration of exposure, and nerve muscle group tested.

Nusinersen was approved by the FDA in late December 2016 and by the EMA in June 2017. Commercialized by Biogen under the name spinraza ${ }^{\circledR}$, this drug probably represents the biggest success of the ASO-based therapy. However, many challenges remain and need to be addressed in the near future. Even if nusinersen leads to global improvement, the response varies from a patient to another and improvement in type 2 patients is less significant than in those with SMA type 1 and there is insufficient evidence of efficacy in SMA types 3 and $4^{75}$. Ongoing studies show that presymptomatic treatment may be an important consideration; nevertheless, in patients with active disease, combination of nusinersen with other drugs, including those targeting peripheral tissues may also prove useful and require additional investigations. The involvement of additional peripheral organs, such as cardiac dysfunctions and distal digits necrosis has indeed been reported in the pathogenesis of the disease progression, especially in the most severe cases ${ }^{76}$. The current mode of administration using intrathecal injections does not address these peripheral issues and can be a risk of tissue damage or infection after multiple administrations. Several groups have successfully worked on alternative, albeit still lumbar, route of injection in patients with severe scoliosis or with metal implantation $^{77-79}$. To date, intrathecal administration is used because most PS-ASOs are not able to cross the BBB despite an effective uptake by brain tissues. Promising alternatives are currently being 
explored at the preclinical level, with $\mathrm{PPMO}^{80}$ or $\operatorname{tcDNA}^{81}$ chemistries which have been shown to cross the BBB after systemic delivery. Besides ASOs, other promising candidates administered systemically are in clinical trials including gene therapy with AAV9 (IV and intrathecal administration), risdiplam, acting as a splicing modifier (oral administration), anti-myostatin antibody and reldesemtiv, a muscle troponin activator (oral administration) (approaches reviewed in ${ }^{82}$ ). Amongst these, only SMN1 gene replacement mediated by the AAV vector AVXS-101 has been approved by the FDA so far and offers the advantage of a single administration in contrast with the repeated injections required for nusinersen.

\section{Myotonic dystrophy}

Another example of inherited neuromuscular disorder which can be targeted by ASO is Myotonic dystrophy type 1 (DM1), which is the most common form of muscular dystrophy in adults with an estimated incidence of 1 per 8,000 individuals worldwide ${ }^{83}$. DM1 is a multisystemic disease characterised by myotonia, muscle weakness, cardiac arrhythmias, insulin resistance and cognitive dysfunction. DM1 is caused by an abnormal expansion of a CTG trinucleotide repeat in the 3'untranslated region of the human dystrophia myotonica protein kinase (DMPK) gene.

Transcription of the DMPK CTG repeats into a highly structured DMPK CUG ${ }^{\exp }$ RNA leads to RNA aggregates, referred to as foci in which the muscle blind-like 1 protein (MBNL1) is found sequestered. Limiting the availability of MBLN1 splicing regulator results in the missplicing of several important muscle-expressed genes including CLCN1, INSR, BIN1, DMD, and SCN5A that have been associated respectively with myotonia, insulin resistance, muscle weakness, dystrophic process, and cardiac conduction defects, all symptoms of $\mathrm{DM} 1^{84}$. Restoring the abnormal splicing of some of these targets using ASOs has been explored and the correction of CLCN1 transcripts was achieved using a PMO for example, leading to reduced myotonia in mouse models of $\mathrm{DM}^{85}$. However, targeting the downstream effects may not address all the symptoms of the disease given the large number of misspliced mRNAs in DM1. Alternatively, therapeutic ASOs targeting directly the DMPK RNA have 
1 been developed over the years, aiming at either degrading the $\mathrm{CUG}^{\mathrm{exp}}$ transcripts using gapmer ASOs

2 recruiting RNase $\mathrm{H}$ (figure 1, left panel) or at releasing sequestered MBNL1 from $\mathrm{CUG}^{\mathrm{exp}}$-containing RNAs by direct competition using steric blocker (fully modified, figure 1 right panel) ASOs. A PMO CAG25 binding to CUG ${ }^{\text {exp }}$ RNA was shown to block its interaction with MBNL1, disperse the nuclear foci and therefore reduce the overall burden of this toxic RNA ${ }^{86}$. Interestingly studies using steric blocker ASOs (PMO as well as 2'OMe modified) found a reduction in CUG repeat transcripts when these ASO should only "block" and not degrade the transcripts, therefore suggesting degradation by another pathway once released from binding with MBNL proteins. Reduction of the CUG ${ }^{\text {exp }}$ RNA and subsequent reduction in myotonia were also induced more directly using gapmer ASO targeted either to the CUG repeats ${ }^{87}$, to the $3^{\prime}$ UTR or to the coding region of the human skeletal actin (HAS) gene in the $H S A^{\mathrm{LR}}$ mouse model, a transgenic mouse carrying 250 CTG repeats in the $3^{\prime}$ UTR of the HSA transgene ${ }^{88}$. Following these encouraging results, lonis Pharmaceuticals designed higher affinity ASOs containing 2'-4'-constrained ethyl (cEt) modifications, which were described with significantly enhanced in vivo potency compared with $2^{\prime}-\mathrm{MOE}-$ modified $\mathrm{ASO}^{89}$. The cEt-modified DMPK ASO demonstrated potent activity in the skeletal and cardiac muscles of normal mice, as well as cynomolgus monkeys ${ }^{90}$. Moreover the same gapmer was shown to improve body weight, muscle strength and muscle histology in the DMSXL mouse model, which harbors a mutant form of the human DMPK gene (carrying $>1,000$ CTG repeats) ${ }^{91}$.

Together with a favourable safety profile, these encouraging preclinical results led to the clinical evaluation of this approach in a human clinical trial (NCT02312011). While the primary objective of the study was safety and tolerability, the results of the trial also revealed insufficient concentration of the therapeutic ASO in muscle tissues following systemic administration and the development of this drug was therefore discontinued ${ }^{84}$. These disappointing results confirmed that delivery remains one of the main challenge of the ASO-therapy for neuromuscular disorders and even more so for DM1. Since the membrane integrity of muscles from patients with DM1 was found no more 
1 permeable than in healthy patients ${ }^{92}$, in contrast to patients with DMD for example, DM1 drugs must

2 overcome the barrier of a fully functional membrane. Therefore, more potent chemistries or

3 improved delivery systems must be developed. Ionis Pharmaceuticals has recently focused on ligand conjugated-ASO and published the enhanced potency of fatty acid conjugated ASO in mouse muscles $^{93}$. In particular, palmitic acid conjugation was shown to increase ASO peak plasma concentration (Cmax) and improve delivery to interstitial space of mouse muscle. However, the same group also reported that the promising palmitate conjugate was found less effective in monkeys, therefore limiting its therapeutic potential in humans ${ }^{94}$.

Among strategies to improve delivery of ASOs in DM1 muscles, CPP conjugates also offer an attractive option. A recent study from Klein and colleagues demonstrated that a low-dose treatment with a Pip6a-conjugated PMO directed against pathogenic CUG ${ }^{\text {exp }}$ repeats was sufficient to achieve an effective concentration of ASOs in muscle fibers and induce an efficient and long-lasting correction of myotonic dystrophy features in DM1 mice as well as in patient-derived cells ${ }^{95}$. Amelioration of the DM1 phenotype included normalization of the transcriptome and reduction in the prevalence of foci-positive fibers. These encouraging results support the clinical development of peptide conjugates for systemic corrective therapy in DM1 but the promise of such compounds still crucially depends on how well they will be tolerated in humans.

\section{Amyotrophic lateral sclerosis}

Amyotrophic lateral sclerosis (ALS) is a progressive neurodegenerative disease affecting motor neurons in the cortex and spinal cord. With a prevalence of approximately 6 cases per 100000 individuals, ALS is the most common motor neuron disease in adults ${ }^{96}$. Symptoms in ALS depend on the neurons affected by the disease, most patients have onset in one limb or two upper or lower limbs in an asymmetric fashion and one-third have bulbar onset. Voluntary muscle action is gradually 
1 affected and patients may become completely paralyzed in the later stages of the disease. In general

2 the death of patients occurs due to a respiratory paralysis generally 3 to 5 years following diagnosis ${ }^{97}$.

3 ALS is considered as a complex genetic disorder without discernible family history in the majority of cases. However, $\geq 30$ genes have been reported to confer a major risk of ALS and evidence suggests roles of oligogenic inheritance and of genetic pleiotropy ${ }^{98}$. In the populations with a family history, four genes account for up to $70 \%$ of all cases, namely, SOD1, C9orf72, TARDBP and FUS ${ }^{98}$. The antisense technology is an attractive option for ALS and different ASOs are currently being developed preclinically and clinically; the most promising approaches targeting these genes are reviewed below.

\subsection{SOD1 mutations}

$12-20 \%$ of familial cases of ALS are due to mutations in the SOD1 gene. More than 100 different mutations in the SOD1 gene confer a toxic gain of function of the SOD1 protein that may impact neuronal function and survival ${ }^{99}$. Reduction of the mutant SOD1 protein concentration can slow progression of SOD1-linked $\mathrm{ALS}^{100}$ and ASOs have therefore been developed in this aim. During the preclinical studies performed in rats and nonhuman primates models, ASOs were shown to effectively target the central nervous system (CNS) after intrathecal administrations, decrease SOD1 concentration and increase survival ${ }^{101}$. Following these encouraging preclinical data, ISIS333611, a 2'MOE-PS gapmer ASO targeting the exon 1 of SOD1 mRNA was further developed and became the first experimental ASO delivered intrathecally into patients for the treatment of a neurodegenerative disease $^{102}$. This clinical study confirmed that intrathecal administration of ASOs into the CNS of patients was well tolerated without dose-limiting toxic effects or safety concerns ${ }^{102}$. Moreover, SOD1 concentrations in brain tissue were found to correlate with SOD1 concentrations in the CSF, which allowed the use of CSF SOD1 protein concentrations as a pharmacodynamic marker for ASO activity in the next clinical trials. Despite being encouraging, ISIS333611 effects were modest and advances in ASO technology in particular for other neuromuscular disorders like SMA identified more effective delivery methods to the CNS as well as more potent ASO designs. Further research highlighted a six 
1 (the 3' UTR part) and resulting in increased survival of transgenic rodents compared to the previous

2 ISI333611 ${ }^{103}$. Preliminary results from the phase $1 \mathrm{~b} / 2 \mathrm{a}$ clinical study with this ASO (NCTO2623699) revealed that intrathecal administration of the highest dose tested of BIIB067 reduced SOD1 concentrations in patients CSF without toxicity, although results must be confirmed on higher number of patients. Currently, two phase 3 clinical trials are ongoing with BIIB067: one to confirm the efficacy, safety, tolerability, pharmacokinetics, and pharmacodynamics of the ASO (NCT02623699) and another to evaluate the long-term safety and tolerability (NCT03070119). The first results of these studies are expected in 2021.

\section{(1)}

\subsection{C9orf72}

$40 \%$ of familial cases of ALS are due to an hexanucleotide expansion (GGGGCC) in the noncoding region of the C9orf72 gene ${ }^{104}$. Several potential mechanisms have been suggested to explain the neurodegeneration caused by this expansion ${ }^{105}$. Amongst them, a toxic gain of function of the RNA, depleting RNA-binding protein similar to the mechanisms of DM1, or a decreased production of the C9orf72 have been proposed. However, the loss of C9orf72 protein alone is not sufficient to create the disease since deletion of the C9orf72 gene in mice did not result in detectable neurodegeneration ${ }^{106}$. Alternatively, it was reported that the C9orf72 mutations lead to the transcription of RNAs containing sense GGGGCC (G4C2) and antisense CCCCGG (C4G2) repeats which can exert toxic gain of function and drive neurodegeneration through the production of different poly-dipeptides ${ }^{107}$. These repeats induce an increase in 5 species of dipeptide repeat proteins: poly(GP), poly(GA), poly(PR), poly(GR), and poly(PA), each shown to aggregate in CNS tissues of individuals with $\mathrm{ALS}^{108}$. The most important one being the poly(GP) because it is C9orf72 specific and its levels are consistent over time, supporting its continued use as a pharmacodynamics biomarker for expansion-targeted therapeutics ${ }^{108}$. Several studies have reported the use of RNase H1-recruiting ASO and shown reduction of RNA foci and dipeptides in cellular as well as mouse models of C9orf72 $\mathrm{ALS}^{105,109}$. In particular, Jiang and colleagues demonstrated that an ASO targeting the region between 
exon $1 \mathrm{a}$ and $1 \mathrm{~b}$ leads to a $60-80 \%$ decrease of repeat-containing C9orf72 RNA levels (with exon 1a) in the cortex and spinal cord and preserves C9orf72 protein encoding RNAs (with exon 1b). Four weeks after a single injection of this ASO, a 55-60\% decrease of sense foci number was observed and both $\operatorname{poly}(\mathrm{GP})$ and poly(GA) were decreased to almost undetectable levels ${ }^{109}$. These results suggest that ASO therapy can mitigate the toxicity from repeat RNAs without exacerbating the disease with a potential loss of C9orf72 function. Based on these findings, clinical studies have been initiated to evaluate the safety, tolerability and pharmacokinetics of BIIB078 (an ASO targeting the same region of C9orf72 gene) $)^{110}$ administered intrathecally to ALS patients with C9orf72 hexanucleotide expansion (NCT03626012 and NCT04288856).

\subsection{Other targets for ALS}

The field has rapidly advanced over the past 5 years and other targets related to TDP-43, ATXN2, FUS or stress pathways are also being investigated as potential therapeutics for ALS ${ }^{111}$. FUS protein is involved in RNA metabolism, including transcription, alternative splicing, and mRNA transport, as well as DNA damage regulation ${ }^{112}$ and FUS mutations account for $\sim 5 \%$ of familial cases of ALS ${ }^{113}$. FUSrelated ALS pathology is characterized by mislocalization of FUS to the cytoplasm and a concomitant reduction in nuclear expression in affected neurons. Loss of nuclear FUS leads to neuronal cell death and accumulation of FUS leads to the formation of toxic stress granules ${ }^{112}$. In their preliminary studies, Zhou and colleagues have demonstrated that FUS is a repressor of its exon 7 and that the exon 7-skipped splice variants of FUS are subjected to nonsense-mediated decay ${ }^{114}$. A 2'OMe-PS ASO was therefore developed to skip exon 7 and ex-vivo studies demonstrated decrease in FUS protein synthesis and restoration of the deficient FUS autoregulation ${ }^{114}$.

Ataxin-2 is an additional target which has been investigated as a therapeutic approach for ALS. Ataxin-2 is an RNA-binding protein involved in RNA metabolism. Presence of high number of CAG trinucleotide repeats in this gene is associated with the severe neurodegenerative disease 
1 spinocerebellar ataxia 2 (SCA2) (more than 33 repeats) but also with an increased risk of ALS (29 to

233 repeat expansions) $)^{115}$. Reducing expression of ataxin-2 was shown to decrease neurodegeneration

3 in several models, thus opening ASO-mediated therapeutic options to treat these diseases. 2'MOE

4

5

6

7

8

9 4 gapmer ASOs targeting human ATXN2 were recently screened and shown to decrease ATXN2 mRNA in cerebella without astroglial and microglial cells activation following ICV injection ${ }^{116}$. A single treatment markedly extended survival of TDP-43 transgenic mice ${ }^{117}$, suggesting the therapeutic potential of this approach. Importantly, ASO-mediated reduction of ataxin2 could represent an effective therapeutic strategy for two neurodegenerative diseases, SCA2 and ALS ${ }^{118}$. It is also important to highlight that it may be beneficial for most forms of ALS since TDP-43 aggregation is a common pathological feature for both sporadic and familial forms of $\mathrm{ALS}^{119}$. However, evidence suggest that ALS related to SOD1-mutations is independent of TDP-43 cascade, implying there would be no benefit with ataxin-2 inhibition ${ }^{120}$.

5

\section{Huntington's disease}

Huntington's disease (HD) is an autosomal dominant neurodegenerative disease characterized by progressive movement dysfunction, cognitive impairment and brain atrophy ${ }^{121}$. HD is caused by CAG expansions in the exon 1 of $H T T$ gene, encoding an elongated polyglutamine tract in the huntingtin protein (HTT). HTT is critical for nerve cells viability and plays a role in orientation of the mitotic spindle, trafficking of autophagosomes in neurons, and in regulating autophagy ${ }^{122}$. While the pathogenesis of HD is still unclear, most published studies suggest a toxic gain of function for the mutant HTT protein which particularly aggregates and has toxic effects on neurons. Gene silencing approaches including the use of ASOs has been investigated to lower the levels of HTT. ASO therapies for HD offer two main options: the allele specific silencing which aims at knocking down specifically the mutant allele or the non-specific silencing which will lower both alleles and therefore all HTT proteins. 
The non-allele specific approach aiming at decreasing the total HTT mRNA and protein can be achieved using gapmer ASOs targeting a sequence common to both alleles. Preclinical studies have demonstrated that the ICV infusion of a 2'MOE gapmer ASO during 2 weeks induced efficient and sustainable reduction of HTT in the CNS of YAC128 mice which express the mutant human HTT transgene ${ }^{121}$. This inhibition of human HTT in mouse models of HD reversed existing behavioral phenotypes and prevented progressive loss of brain mass ${ }^{123}$. Similar results were also obtained in Rhesus monkeys after intrathecal infusions ${ }^{121}$. Based on these encouraging results, a clinical phase 1b/2a study was initiated with this 2'MOE gapmer (HTTRx later renamed RG6042) targeting an exonic sequence in the HTT RNA. RG6042 was delivered by bolus intrathecal injection every 3 months in 46 patients with early stage of HD and five doses were investigated from 10 to $120 \mathrm{mg}^{124}$. The treatment was well-tolerated and a dose-dependent reduction of mutant HTT (mHTT) concentration, which appeared to plateau at higher doses was detected in the CSF $^{125}$. An open-label extension study was started (NCT03342053) as well as a pivotal phase 3 (NCT03761849) at the dose of 120 mg monthly or bimonthly during 25 months to evaluate the long term efficacy and safety of RG6042 $2^{126}$.

\subsection{Allele specific approaches}

As previously mentioned and given that HTT is involved in nerve cells viability, there is a concern that non-allele specific approach aiming at lowering total HTT may be detrimental for normal neural function. To circumvent this potential risk, some ASOs have been developed to inhibit specifically the mHTT. One way to preferentially silence the mutant allele is to directly target the CAG repeats which are more represented on the mutant allele. This was achieved in preclinical studies using a steric blocker ASO, fully modified 2'OMe-PS named (CUG)7. The first result obtained with this ASO in vitro confirmed a difference between the inhibition of WT HTT and mHTT with a higher effect with the mutant gene in HD fibroblasts ${ }^{127}$. This difference was confirmed in vivo in HD mouse models with a $15-60 \%$ reduction of both soluble and aggregated mutant HTT protein observed in striatum, hippocampus and cortex of treated mice ${ }^{128}$. In the same study, the authors also investigated the 
1 effect of the CUG7 ASO on several endogenous genes with shorter non-expanded CAG repeats and reported no change in expression levels of any of these genes (5 to 20 CAG repeats) suggesting the importance of CAG repeat length for CUG7-mediating silencing ${ }^{128}$.

While these encouraging results may suggest an interesting alternative HTT-lowering strategy for HD, this approach has not yet moved to the clinic and the use of CAG targeting ASO is still debated because CAG repeats are also present on the normal allele. Since most patients have a number of CAG repeats relatively close between both alleles, the allele specificity may become more challenging in the clinic. Thus, unambiguous allele-specific approaches have been developed and in particular ASO targeting single-nucleotide polymorphisms (SNP) that are linked to the expanded CAG repeat. 91 SNP were found across the HTT gene region but the development of only 3 ASOs may enable selective treatment of a maximum of $80 \%$ of HD patients ${ }^{129}$. Several preclinical studies using ASO targeting SNPs have demonstrated robust $\mathrm{mHTT}$ suppression and the subsequent reduction of cognitive and behavioral impairment in HD mouse models ${ }^{130-132}$. Wave Live Sciences has been running parallel trials (NCT03225846 and NCT03225833) with two new ASOs, which could theoretically target two-thirds of the HD population; one specific to the region rs362331 (WVE120101) and the other to rs362307 (WVE-120102). Preliminary results suggest that WVE-120102 induced a reduction of $12 \%$ of $\mathrm{mHTT}$ protein in the CSF of patients treated intrathecally with the highest dose, i.e. $16 \mathrm{mg}^{133}$. While this figure may appear lower than the previously reported $40-60 \%$ reduction of total HTT obtained with RG6042, it is important to note the significant difference in the doses of drug used (16 mg for WVE-120102 vs $120 \mathrm{mg}$ of RG6042). Based on their results showing their drug was safe at lower doses, Wave has also announced it will now add an extra dosing arms to the PRECISION-HD trials to test higher doses (32 mg per injection) $)^{133}$.

Altogether these results highlight that both allele specific and non-allele specific ASO approaches are moving forward for the treatment for HD and the long term results of these trials will definitely shed some light on the debated role of huntingtin in adults and the safety of a non-allele specific approach. 


\section{CONCLUDING REMARKS}

The different examples presented above highlight the variable therapeutic outcomes of the ASO therapies for neuromuscular and neurodegenerative diseases. While some of these drugs have truly demonstrated a significant impact on patient lives, such as the profound clinical benefit observed in SMA patients treated with nusinersen, others have failed to do so. Some of the main reasons for these differences are the target tissue and the route of administration which depend on the disease itself. Indeed the therapeutic outcomes appear much better for diseases where local delivery is possible, as exemplified with SMA, ALS and HD. On the other hand, when the entire musculature must be reached and systemic delivery is the only possible route of administration, things get a bit more complicated, as illustrated by the unsuccessful trial for DM1 and the still limited clinical benefit reported in DMD patients (despite the approval of 3 ASO drugs). Paradoxically the CNS or motor neurons may have been considered more difficult targets to reach than skeletal muscles, but it turns out that ASOs present a relatively good uptake in brain tissues after intrathecal injection.

Overall this illustrates more than ever that delivery is key in the success of ASO therapies and that further efforts are needed to improve it. The development of improved targeted delivery is not only required for muscular dystrophies for which systemic administration is needed but would also be advantageous for the diseases currently treated via intrathecal injection. Antisense treatment is administered via intrathecal route because ASO do not cross the BBB, but this way of administration remains an invasive procedure. Besides the obvious clinical challenges, especially when repeated injections are required, it limits the range of applications to severe and rapidly progressive diseases based on the benefit-risk concept. Moreover it neglects the issue of delivering ASOs to the periphery, which could be crucial for some of these diseases like HD or SMA for example ${ }^{76,134}$. In this context, the development of new ASOs or delivery systems which could deal with the issue of both peripheral and central tissue penetration is also an important milestone. 
2 Development of more potent chemistries or novel delivery systems has become a very active line of 3 research in the past few years ${ }^{26}$. Amongst these potentially interesting technological advances was the advent of stereopure ASO chemistry developed by Wave Life sciences, permitting chirally controlled ASO synthesis, with improvements in both potency and safety. However, in spite of having raised hopes in the DMD community, the recent clinical results did not confirm such improved potency and Wave announced the discontinuation of their DMD ASO program. This highlights the caution that is needed in interpreting in vitro data, since the apparent $52 \%$ of dystrophin restoration measured in human cells in vitro vs $1 \%$ with the PMO clearly did not translate into the same results in the clinic.

There are many opportunities to further improve the ASO platform and a plethora of delivery technologies are emerging to overcome the very poor intracellular bioavailability of nucleic acid drugs. The recent development (and approval) of ASO incorporating GalNAc (N-Acetylgalactosamine) conjugates showing 20 - to 30 -fold increases in potency has proven the possibility of creating better antisense drugs. These improvements have impacts on many different levels since increasing potency not only reduces the doses of drug to be used, which may impact the cost, but also reduces or eliminates some of the adverse events often associated with high doses of ASOs. Inspired by the success of the GaINAc conjugates, the conjugation of ASO to various ligands such as peptides or lipids has been explored. In this context, PPMO have shown very promising results in preclinical studies for $\mathrm{DMD}^{56}, \mathrm{SMA}^{80}$ and $\mathrm{DM}^{95}$. Similarly, lipid-conjugated cEt-ASO have also demonstrated enhanced potency in muscles ${ }^{93}$. Recently, conjugation of ASOs to antibodies has also gained increasing interest and several groups and companies such as Avidity biosciences have started exploring their potential. However, the promise of all these novel compounds still crucially depends on how well they will be tolerated in humans. 
1

Other promising therapeutic approaches have been developed for most of the diseases mentioned in this review and in particular gene replacement therapies mediated by AAV vectors which are particularly useful tools to overcome the delivery challenges in NMDs. AVXS-101, an AAV9 vector designed for SMN1 replacement was approved by the FDA in 2019 for the treatment of SMA pediatric patients. Given the ability of AAV9 vectors to cross the BBB and the persistence of AAV genomes in tissues, AVXS-101 (commercialized as Zolgensma ${ }^{\circledR}$ ) offers the advantage of being a single, one-time intravenous (IV) infusion in contrast with nusinersen which is administered intrathecally several times/year.

Zolgensma ${ }^{\circledR}$ was the first (and only so far) gene therapy drug for SMA and is currently the world's most expensive drug with a price of $\$ 2.1 \mathrm{M}$ announced by Novartis. In comparison, spinraza ${ }^{\circledR}$ (nusinersen) medication is estimated to cost $\$ 750,000$ during the first year of treatment and then $\$ 375,000$ annually thereafter ${ }^{135}$. Gene and ASO therapies are therefore extremely expensive therapies with record high prices, which require a careful consideration of reimbursement and insurance company coverage of medication costs. Nonetheless, it is important to put the costs and benefits of these therapies into perspective, since they offer substantial health gains compared to less expensive conventional treatments and thus may have comparable value in terms of costeffectiveness ${ }^{136}$.

AAV gene therapy programs are also being developed for the treatment of DMD using AAV vectors carrying a microdystrophin transgene. Several clinical trials have been launched to evaluate this strategy in DMD patients and preliminary data have revealed encouraging results with significant restoration of dystrophin expression ${ }^{138}$. The AAV-microdystrophin approach for DMD offers the advantage of being applicable to most DMD patients as opposed to the personalised ASO therapy targeting specific exons. Yet, the limited packaging capacity of AAV vectors imposes a much shorter dystrophin (microdystrophin) which may turn out less functional than the potential dystrophin resulting from exon skipping. As for the SMA gene therapy, the medication would only require a 
1 single IV administration which also compares favourably to the lifelong treatment required with ASO.

2 However, the gene therapy's effectiveness durability still remains to be assessed over long period of

3 time in patients because preclinical studies using AAV vectors in animal models of DMD have

4 suggested a progressive loss of AAV genomes in muscles ${ }^{61,139}$. This is of significant importance

5 considering the immunological challenges (such as neutralizing antibodies) faced by the AAV-gene

6 therapy, currently impairing re-administration. In that regard, ASO do not trigger neutralizing

7 antibodies and can therefore be advantageously re-administered. It is thus not excluded to consider

8 future combination therapies of AAV and ASO as it has already been explored in SMA Type 1 patients

9 treated with both Nusinersen and AVXS-101 ${ }^{137}$.

12 In conclusion, ASO therapies have made tremendous progress in the past 15 years as illustrated by

13 the numerous approvals of ASOs for the treatment of neuromuscular disorders as well as additional diseases not discussed in this review. Even though many challenges remain, notably with respect to targeted delivery, these first successes have paved the way for future disease modifying-therapies based on the ASO technology. 


\section{FIGURE LEGENDS}

Figure 1: ASOs mechanisms of action. ASOs may exert different effects depending on their structure and design. To induce mRNA degradation via RNase $\mathrm{H}$, ASO must be designed as gapmers (I) with a central core of 8 to 10 consecutive DNA nucleotides to support binding and cleavage by RNase H1 (in blue), flanked by modified nucleotides for nuclease resistance (in red). Fully modified ASO (II) are not able to elicit RNase $\mathrm{H}$ activity and they are commonly used as splice switchers (A) to manipulate alternative splicing (exon skipping or exon inclusion); or as steric blockers (B) to either block protein translation or inhibit RNA mediated toxicity by competing with protein binding. ASO: antisense oligonucleotide.

11

\section{TABLES}

Table 1. List of clinical trials for DMD, SMA, DM1, ALS and HD. Abbreviations: 2'OMe-PS: 2'O-methyl with phosphorothioate link; 2'OMe/ENA: 2'OMe-PS and 2'-O,4'-C-ethylene-bridged nucleic acid chimera ASO; 2'MOE-PS: 2'O-methoxyethyl with phosphorothioate link; ALS : Amyotrophic lateral sclerosis; cET: 2'-4'-constrained ethyl; DM1: Myotonic dystrophy type 1; DMD: Duchenne muscular dystrophy; Ex: exon; HD : Huntington's disease; HTT : Huntington's gene; IM: intramuscular; IV: intravenous; PMO: Phosphorodiamidate Morpholino Oligomer; PPMO: peptide conjugated PMO; SMA: Spinal muscular atrophy; Subcut.: Subcutaneous 
Figure 1

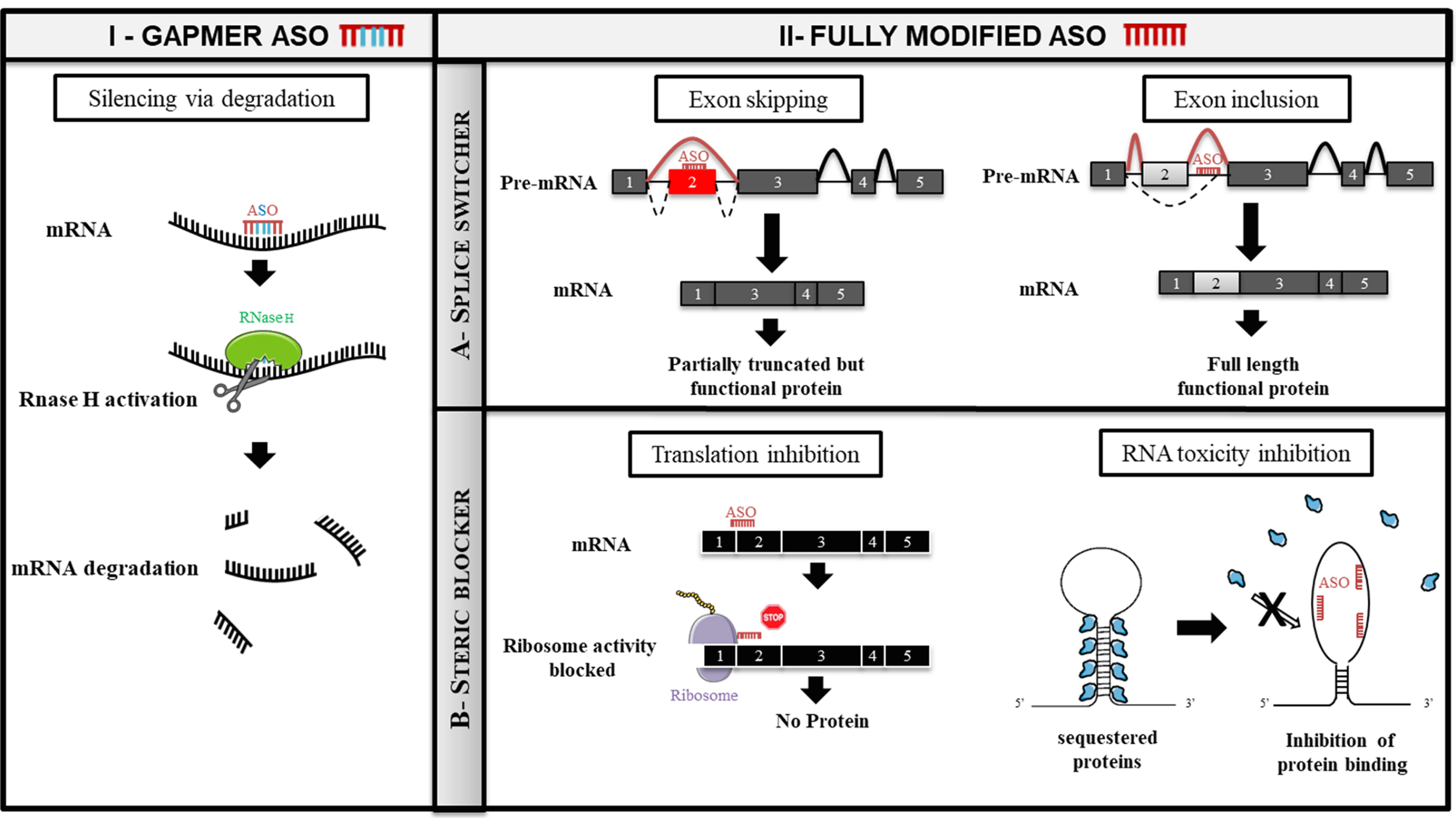




\begin{tabular}{|c|c|c|c|c|c|c|c|}
\hline $\begin{array}{c}\text { Disease } \\
\text { (target } \\
\text { gene) }\end{array}$ & Drug name & $\begin{array}{l}\text { Chemistry } \\
\text { and } \\
\text { mecanism }\end{array}$ & Phase & $\begin{array}{c}\text { Administration } \\
\text { Route }\end{array}$ & $\begin{array}{l}\text { Clinical } \\
\text { status }\end{array}$ & $\begin{array}{c}\text { registration } \\
\text { number and } \\
\text { age of } \\
\text { patients }\end{array}$ & Sponsor \\
\hline $\begin{array}{l}\text { DMD } \\
\text { (Ex20) }\end{array}$ & A019 & $\begin{array}{l}\text { 2'OMePS } \\
\text { exon } \\
\text { skipping }\end{array}$ & $1 / 2$ & $\begin{array}{c}\text { IV } \\
(0.5 \mathrm{mg} / \mathrm{kg})\end{array}$ & completed & & $\begin{array}{c}\text { Kobe } \\
\text { university, } \\
\text { Japan }\end{array}$ \\
\hline \multirow{15}{*}{$\begin{array}{l}\text { DMD } \\
\text { (Ex51) }\end{array}$} & \multirow{4}{*}{$\begin{array}{c}\text { PRO051 } \\
\text { (Drisapersen }{ }^{\circledR} \text { ) }\end{array}$} & \multirow{4}{*}{$\begin{array}{l}\text { 2'OMePS } \\
\text { exon } \\
\text { skipping }\end{array}$} & 1 & $\begin{array}{c}\mathrm{IM} \\
(0.8 \mathrm{mg}) \\
\end{array}$ & completed & & Prosensa \\
\hline & & & $1 / 2$ & $\begin{array}{c}\text { Subcut. } \\
\text { (escalating } \\
\text { doses) and IV }\end{array}$ & $\begin{array}{l}\text { Terminated } \\
(2008-2016)\end{array}$ & $\begin{array}{l}\text { NCT01910649 } \\
\text { (5 to } 16 \text { years) }\end{array}$ & \multirow{2}{*}{ Biomarin } \\
\hline & & & \multirow{2}{*}{3} & $\begin{array}{c}\text { Subcut. and IV } \\
(6 \mathrm{mg} / \mathrm{kg} \text { and } \\
3 \mathrm{mg} / \mathrm{kg})\end{array}$ & $\begin{array}{l}\text { Terminated } \\
(2013-2016)\end{array}$ & $\begin{array}{c}\text { NCT01803412 } \\
\text { (5 years and } \\
\text { older) }\end{array}$ & \\
\hline & & & & $\begin{array}{l}\text { Subcut. } \\
(6 \mathrm{mg} / \mathrm{kg})\end{array}$ & $\begin{array}{c}\text { Terminated } \\
(2011-2014)\end{array}$ & $\begin{array}{c}\text { NCT01480245 } \\
\text { (5 years and } \\
\text { older) }\end{array}$ & GSK \\
\hline & \multirow{6}{*}{$\begin{array}{l}\text { Exondys } 51^{\circledR} \\
\text { (AVI-4658 / } \\
\text { Eteplirsen) } \\
\text { Approved by } \\
\text { FDA (2016)- } \\
\text { rejected by } \\
\text { EMA (2018) }\end{array}$} & \multirow{6}{*}{$\begin{array}{l}\text { PMO } \\
\text { exon } \\
\text { skipping }\end{array}$} & $1 / 2$ & $\begin{array}{c}\mathrm{IM} \\
\text { (0.09 to } 0.9 \mathrm{mg} \text { ) }\end{array}$ & $\begin{array}{c}\text { Completed } \\
(2007-2009)\end{array}$ & $\begin{array}{c}\text { NCT00159250 } \\
\text { (10 to } 17 \\
\text { years) }\end{array}$ & $\begin{array}{c}\text { Imperial } \\
\text { College of } \\
\text { London / } \\
\text { AVI } \\
\text { biopharma }\end{array}$ \\
\hline & & & $1 / 2$ & $\begin{array}{c}\mathrm{IV} \\
(0.5,1,2,4,10 \\
\text { and } 20 \mathrm{mg} / \mathrm{kg}) \\
\end{array}$ & $\begin{array}{c}\text { Completed } \\
(2009-2010)\end{array}$ & $\begin{array}{l}\text { NCT00844597 } \\
\text { (5 to } 15 \text { years) }\end{array}$ & \multirow{5}{*}{ Sarepta } \\
\hline & & & 2 & $\begin{array}{l}\text { IV (30 and } \\
50 \mathrm{mg} / \mathrm{kg})\end{array}$ & $\begin{array}{c}\text { Completed } \\
(2011-2012, \\
2012-2017, \\
2014-2018 \\
\text { and 2015- } \\
2018)\end{array}$ & $\begin{array}{c}\text { NCT01396239 } \\
\text { and } \\
\text { NCT01540409 } \\
\text { (7 to } 13 \text { years) } \\
\text { NCT02286947 } \\
\text { (7 to } 21 \text { years) } \\
\text { NCT02420379 } \\
\text { (4 to } 6 \text { years) }\end{array}$ & \\
\hline & & & 3 & $\begin{array}{c}\mathrm{IV} \\
(30 \mathrm{mg} / \mathrm{kg}) \\
\end{array}$ & $\begin{array}{c}\text { Completed } \\
(2014-2019) \\
\end{array}$ & $\begin{array}{l}\text { NCT02255552 } \\
\text { ( } 7 \text { to } 16 \text { years) }\end{array}$ & \\
\hline & & & 3 & $\begin{array}{c}\text { IV } \\
\text { (2 high doses) }\end{array}$ & $\begin{array}{c}\text { Recruiting } \\
(2019-2024)\end{array}$ & $\begin{array}{l}\text { NCT03992430 } \\
\text { (7 to } 13 \text { years) }\end{array}$ & \\
\hline & & & 2 & \begin{tabular}{|c|} 
IV \\
$\begin{array}{c}(2,4,10,20, \text { and } \\
30 \mathrm{mg} / \mathrm{kg})\end{array}$ \\
\end{tabular} & $\begin{array}{c}\text { Active, not } \\
\text { recruiting } \\
(2017-2021) \\
\end{array}$ & $\begin{array}{c}\text { NCT03218995 } \\
\text { (6 to } 48 \mathrm{Mo} \\
\text { babies) }\end{array}$ & \\
\hline & \multirow{2}{*}{$\begin{array}{l}\text { WVE-210201 } \\
\text { (Suvodirsen }^{\oplus} \text { ) }\end{array}$} & \multirow{2}{*}{$\begin{array}{l}\text { Stereopure } \\
\text { exon } \\
\text { skipping }\end{array}$} & 1 & $\begin{array}{c}\text { IV } \\
(0.5,1,2,5 \text { and } \\
10 \mathrm{mg} / \mathrm{kg})\end{array}$ & $\begin{array}{c}\text { Completed } \\
(2018-2019)\end{array}$ & $\begin{array}{l}\text { NCT03508947 } \\
\text { ( } 5 \text { to } 18 \text { years) }\end{array}$ & \multirow{2}{*}{$\begin{array}{l}\text { Wave Life } \\
\text { Sciences }\end{array}$} \\
\hline & & & $2 / 3$ & $\begin{array}{c}\text { IV } \\
\text { (2 doses) }\end{array}$ & $\begin{array}{c}\text { Terminated } \\
(2019-2020)\end{array}$ & $\begin{array}{l}\text { NCT03907072 } \\
\text { (5 to } 12 \text { years) }\end{array}$ & \\
\hline & \multirow{3}{*}{ SRP-5051 } & \multirow{3}{*}{$\begin{array}{l}\text { PPMO } \\
\text { exon } \\
\text { skipping }\end{array}$} & 1 & IV & $\begin{array}{c}\text { Completed } \\
(2018-2019)\end{array}$ & $\begin{array}{c}\text { NCT03375255 } \\
\text { (12 years and } \\
\text { older) }\end{array}$ & \multirow{3}{*}{ Sarepta } \\
\hline & & & $1 / 2$ & $\begin{array}{l}\text { (escalating } \\
\text { doses) }\end{array}$ & $\begin{array}{c}\text { Recruting } \\
(2018-2024)\end{array}$ & $\begin{array}{c}\text { NCT03675126 } \\
\text { (7 years and } \\
\text { older) }\end{array}$ & \\
\hline & & & 2 & $\begin{array}{c}\text { IV (12 or } 24 \\
\text { week) }\end{array}$ & $\begin{array}{c}\text { Recruting } \\
(2019-2021)\end{array}$ & $\begin{array}{l}\text { NCT04004065 } \\
\text { (4 to } 21 \text { years) }\end{array}$ & \\
\hline
\end{tabular}




\begin{tabular}{|c|c|c|c|c|c|c|c|}
\hline \multirow{2}{*}{$\begin{array}{l}\text { DMD } \\
\text { (Ex44) }\end{array}$} & \multirow[b]{2}{*}{ PRO044 } & \multirow{2}{*}{$\begin{array}{l}\text { 2'OMePS } \\
\text { exon } \\
\text { skipping }\end{array}$} & $1 / 2$ & $\begin{array}{c}\text { Subcut. }(0.5,1.5, \\
5,8,10 \text { and } 12 \\
\mathrm{mg} / \mathrm{kg}) \text { and IV } \\
(1.5,5 \text { and } 8 \\
\mathrm{mg} / \mathrm{kg})\end{array}$ & $\begin{array}{l}\text { Completed } \\
(2009-2013)\end{array}$ & $\begin{array}{l}\text { NCT01037309 } \\
\text { (5 to } 16 \text { years) }\end{array}$ & \multirow{2}{*}{ Biomarin } \\
\hline & & & 2 & $\begin{array}{c}\text { Subcut. (6 } \\
\mathrm{mg} / \mathrm{kg} \text { ) and IV (6 } \\
\text { and } 9 \mathrm{mg} / \mathrm{kg} \text { ) }\end{array}$ & $\begin{array}{l}\text { Terminated } \\
(2014-2016)\end{array}$ & $\begin{array}{c}\text { NCT02329769 } \\
\text { (9 to } 20 \text { years) } \\
\text { NCT02958202 } \\
\text { (5 years and } \\
\text { older) }\end{array}$ & \\
\hline \multirow{4}{*}{$\begin{array}{l}\text { DMD } \\
\text { (Ex45) }\end{array}$} & PRO045 & $\begin{array}{c}\text { 2'OMePS } \\
\text { exon } \\
\text { skipping }\end{array}$ & $1 / 2$ & $\begin{array}{l}\text { Subcut. } \\
\text { (0.15 to } 9 \mathrm{mg} / \mathrm{kg} \text { ) }\end{array}$ & $\begin{array}{l}\text { Terminated } \\
(2013-2016)\end{array}$ & $\begin{array}{l}\text { NCT01826474 } \\
\text { (5 to } 18 \text { years) }\end{array}$ & Biomarin \\
\hline & \multirow{2}{*}{$\begin{array}{c}\text { SRP-4045 } \\
\text { (casimersen }^{\circledR} \text { ) }\end{array}$} & \multirow{2}{*}{$\begin{array}{c}\text { PMO } \\
\text { exon } \\
\text { skipping }\end{array}$} & 1 & $\begin{array}{c}\text { IV } \\
\text { (4 dose levels) }\end{array}$ & $\begin{array}{c}\text { Completed } \\
(2015-2018)\end{array}$ & $\begin{array}{l}\text { NCT02530905 } \\
\text { (7 to } 21 \text { years) }\end{array}$ & \multirow{2}{*}{ Sarepta } \\
\hline & & & 3 & $\begin{array}{c}\mathrm{IV} \\
(30 \mathrm{mg} / \mathrm{kg})\end{array}$ & $\begin{array}{c}\text { Recruiting } \\
(2016-2023)\end{array}$ & $\begin{array}{l}\text { NCT02500381 } \\
\text { (7 to } 13 \text { years) }\end{array}$ & \\
\hline & DS-5141b & $\begin{array}{c}\text { 2'OMe/ENA } \\
\text { exon } \\
\text { skipping }\end{array}$ & $1 / 2$ & $\begin{array}{c}\text { Subcut. } \\
(0.1,0.5,2 \text { and } 6 \\
\mathrm{mg} / \mathrm{kg})\end{array}$ & $\begin{array}{l}\text { Active, not } \\
\text { recruiting } \\
(2015-2020) \\
\end{array}$ & $\begin{array}{r}\text { NCT02667483 } \\
\text { (5 to } 10 \text { years) }\end{array}$ & $\begin{array}{c}\text { Daiichi } \\
\text { Sankyo Co. }\end{array}$ \\
\hline \multirow{7}{*}{$\begin{array}{l}\text { DMD } \\
\text { (Ex53) }\end{array}$} & PRO053 & $\begin{array}{l}\text { 2'OMePS } \\
\text { exon } \\
\text { skipping } \\
\end{array}$ & 2 & $\begin{array}{c}\text { Subcut. }(1,3,6 \\
\text { and } 9 \mathrm{mg} / \mathrm{kg}) \text { and } \\
\mathrm{IV}\end{array}$ & $\begin{array}{l}\text { Terminated } \\
(2013-2016)\end{array}$ & $\begin{array}{l}\text { NCT01957059 } \\
\text { (5 to } 18 \text { years) }\end{array}$ & Biomarin \\
\hline & \multirow{4}{*}{$\begin{array}{c}\text { NS-065/NCNP- } \\
01 \\
\text { (Viltolarsen }^{\circledR} \text { ) } \\
\text { Approved in } \\
\text { Japan (2020) }\end{array}$} & \multirow{4}{*}{$\begin{array}{l}\text { PMO } \\
\text { exon } \\
\text { skipping }\end{array}$} & 1 & $\begin{array}{c}\text { IV } \\
(1.25,5 \text { and } 20 \\
\mathrm{mg} / \mathrm{kg})\end{array}$ & $\begin{array}{l}\text { Completed } \\
(2013-2015)\end{array}$ & $\begin{array}{l}\text { NCT02081625 } \\
\text { (5 to } 18 \text { years) }\end{array}$ & $\begin{array}{c}\text { National } \\
\text { Center of } \\
\text { Neurology } \\
\text { and } \\
\text { Psychiatry, } \\
\text { Japan } \\
\end{array}$ \\
\hline & & & 2 & $\begin{array}{c}\text { IV } \\
(40 \text { and } 80 \\
\mathrm{mg} / \mathrm{kg})\end{array}$ & $\begin{array}{l}\text { Completed } \\
(2016-2018)\end{array}$ & $\begin{array}{r}\text { NCT02740972 } \\
\text { (4 to } 9 \text { years) }\end{array}$ & \multirow{3}{*}{$\begin{array}{l}\text { NS Pharma, } \\
\text { Inc. }\end{array}$} \\
\hline & & & 3 & $\begin{array}{c}\mathrm{IV} \\
(80 \mathrm{mg} / \mathrm{kg})\end{array}$ & $\begin{array}{l}\text { Recruiting } \\
(2019-2024)\end{array}$ & $\begin{array}{l}\text { NCT04060199 } \\
\text { (4 to } 7 \text { years) }\end{array}$ & \\
\hline & & & 2 & $\begin{array}{c}\text { IV } \\
\text { (40 and } 80 \\
\mathrm{mg} / \mathrm{kg}) \\
\text { Child (4 to } 10 \\
\text { years old) }\end{array}$ & $\begin{array}{l}\text { Active, not } \\
\text { recruiting } \\
(2017-2021)\end{array}$ & $\begin{array}{l}\text { NCT03167255 } \\
\text { (4 to } 10 \text { years) }\end{array}$ & \\
\hline & \multirow{2}{*}{$\begin{array}{c}\text { SRP-4053 } \\
\text { (Golodirsen }^{\circledR} \\
\text { Vyondys } 53^{\circledR} \text { ) } \\
\text { Approved by } \\
\text { FDA (2019) } \\
\end{array}$} & \multirow{2}{*}{$\begin{array}{c}\text { PMO } \\
\text { exon } \\
\text { skipping }\end{array}$} & $1 / 2$ & $\begin{array}{c}\text { IV } \\
(4,10,20 \text { and } 30 \\
\mathrm{mg} / \mathrm{kg})\end{array}$ & $\begin{array}{c}\text { Completed } \\
(2015-2019)\end{array}$ & $\begin{array}{l}\text { NCT02310906 } \\
\text { (6 to } 15 \text { years) }\end{array}$ & \multirow[t]{2}{*}{ Sarepta } \\
\hline & & & 3 & $\begin{array}{c}\mathrm{IV} \\
(30 \mathrm{mg} / \mathrm{kg}) \\
\end{array}$ & $\begin{array}{c}\text { Recruiting } \\
(2016-2023)\end{array}$ & $\begin{array}{l}\text { NCTO2500381 } \\
\text { (7 to } 13 \text { years) }\end{array}$ & \\
\hline \multirow{4}{*}{ SMA } & \multirow{4}{*}{$\begin{array}{c}\text { ISIS396443 } \\
\text { (Nusinersen }^{\circledR}= \\
\text { Spinraza }^{\circledR} \text { ) } \\
\text { Approved by } \\
\text { FDA (2016) } \\
\text { and EMA } \\
(2017)\end{array}$} & \multirow{4}{*}{$\begin{array}{l}\text { 2'-MOE-PS } \\
\text { Exon } \\
\text { inclusion }\end{array}$} & 1 & $\begin{array}{c}\text { Intrathecal } \\
(1,3,6 \text { and } \\
9 \mathrm{mg})\end{array}$ & $\begin{array}{c}\text { Completed } \\
(2011-2013 \\
\text { and 2013- } \\
2014) \\
\end{array}$ & $\begin{array}{c}\text { NCT01494701 } \\
\text { NCT01780246 } \\
\text { (2-14 years) }\end{array}$ & \multirow{4}{*}{ Biogen } \\
\hline & & & $1 / 2$ & $\begin{array}{c}\text { Intrathecal } \\
(3,6,9 \text { and } 12 \\
\mathrm{mg})\end{array}$ & $\begin{array}{l}\text { Completed } \\
(2012-2015)\end{array}$ & $\begin{array}{c}\text { NCT01703988 } \\
\text { (2-15 years) }\end{array}$ & \\
\hline & & & 1 & $\begin{array}{l}\text { Intrathecal } \\
\text { (12 mg) }\end{array}$ & $\begin{array}{l}\text { Completed } \\
(2014-2017)\end{array}$ & $\begin{array}{c}\text { NCT02052791 } \\
\text { (extension of } \\
\text { NCT01703988) }\end{array}$ & \\
\hline & & & 2 & $\begin{array}{l}\text { Intrathecal } \\
\text { (6 and } 12 \mathrm{mg} \text { ) }\end{array}$ & $\begin{array}{l}\text { Completed } \\
(2013-2017)\end{array}$ & $\begin{array}{c}\text { NCT01839656 } \\
\text { (3 weeks-7 } \\
\text { months) }\end{array}$ & \\
\hline
\end{tabular}




\begin{tabular}{|c|c|c|c|c|c|c|c|}
\hline & & & 2 & $\begin{array}{c}\text { Intrathecal } \\
\text { (9.6 to } 12 \mathrm{mg} \text { ) }\end{array}$ & $\begin{array}{c}\text { Terminated } \\
(2015-2018)\end{array}$ & $\begin{array}{r}\text { NCT02462759 } \\
\text { ( } \leq 18 \text { months) }\end{array}$ & \\
\hline & & & 3 & $\begin{array}{c}\text { Intrathecal } \\
\text { (9.6 to } 12 \mathrm{mg} \text { ) }\end{array}$ & $\begin{array}{l}\text { Active } \\
(2015-)\end{array}$ & $\begin{array}{c}\text { NCT02594124 } \\
\text { (extension of } \\
\text { NCT02462759) }\end{array}$ & \\
\hline & & & 2 & $\begin{array}{c}\text { Intrathecal } \\
(12 \mathrm{mg})\end{array}$ & $\begin{array}{l}\text { Active } \\
(2015-)\end{array}$ & $\begin{array}{l}\text { NCT02386553 } \\
\text { ( } \leq 6 \text { weeks) }\end{array}$ & \\
\hline & & & 3 & $\begin{array}{c}\text { Intrathecal } \\
(2.4 \mathrm{mg})\end{array}$ & $\begin{array}{c}\text { Terminated } \\
\text { (2014- } \\
2016) \\
\end{array}$ & $\begin{array}{c}\text { NCT02193074 } \\
\text { (<7 months old } \\
\text { babies) }\end{array}$ & \\
\hline & & & 3 & $\begin{array}{c}\text { Intrathecal } \\
(12 \mathrm{mg})\end{array}$ & $\begin{array}{c}\text { Completed } \\
(2014-2017)\end{array}$ & $\begin{array}{c}\text { NCT02292537 } \\
\text { (2-12 years) }\end{array}$ & \\
\hline & & & 2 & Intrathecal & $\begin{array}{c}\text { Recruiting } \\
(2018-2022)\end{array}$ & $\begin{array}{c}\text { NCT03709784 } \\
\text { (18 to } 70 \\
\text { years) }\end{array}$ & $\begin{array}{c}\text { Washington } \\
\text { University } \\
\text { School of } \\
\text { Medicine }\end{array}$ \\
\hline DM1 & ISIS-DMPKRx & $\begin{array}{c}\text { cET } \\
\text { gapmer }\end{array}$ & $1 / 2$ & Subcut. & $\begin{array}{c}\text { Completed } \\
(2014-2016)\end{array}$ & NCT02312011 & $\begin{array}{c}\text { Ionis } \\
\text { Pharma. }\end{array}$ \\
\hline \multirow{2}{*}{$\begin{array}{c}\text { ALS } \\
\text { (SOD1) }\end{array}$} & \multirow{2}{*}{$\begin{array}{c}\text { BllB067 } \\
\text { (Tofersen }{ }^{\circledR} \text { ) }\end{array}$} & \multirow{2}{*}{$\begin{array}{l}\text { 2'MOE-PS } \\
\text { Gapmer }\end{array}$} & 1 & $\begin{array}{c}\text { Intrathecal } \\
(0.15,0.5,1.5 \\
\text { and } 3 \mathrm{mg})\end{array}$ & $\begin{array}{c}\text { Completed } \\
(2010-2012)\end{array}$ & NCT01041222 & $\begin{array}{c}\text { lonis } \\
\text { Pharma. }\end{array}$ \\
\hline & & & 3 & $\begin{array}{c}\text { Intrathecal } \\
(20,40,60 \text {, or } \\
100 \mathrm{mg})\end{array}$ & $\begin{array}{c}\text { Recruiting } \\
\text { (2016-2021 } \\
\text { and 2017- } \\
\text { 2023) }\end{array}$ & $\begin{array}{l}\text { NCT02623699 } \\
\text { NCT03070119 }\end{array}$ & Biogen \\
\hline $\begin{array}{c}\text { ALS } \\
\text { (C9orf72) }\end{array}$ & $\begin{array}{c}\text { BIIB078 } \\
\left(\text { (IONIS-C9Rx }{ }^{\oplus}\right)\end{array}$ & $\begin{array}{l}\text { 2'MOE-PS } \\
\text { Gapmer }\end{array}$ & 1 & Intrathecal & $\begin{array}{l}\text { Active, not } \\
\text { recruiting } \\
\text { (2018-2021 } \\
\text { and 2020- } \\
2023)\end{array}$ & $\begin{array}{l}\text { NCT03626012 } \\
\text { NCT04288856 }\end{array}$ & Biogen \\
\hline \multirow{4}{*}{ HD (HTT) } & \multirow{2}{*}{$\begin{array}{c}\text { RO7234292 = } \\
\text { RG6042 = } \\
\text { ISIS 443139 = } \\
\text { IONIS-HTTRx }{ }^{\circledR} \\
\left(\text { Tominersen }^{\circledR} \text { ) }\right.\end{array}$} & \multirow{2}{*}{$\begin{array}{l}\text { 2'MOE-PS } \\
\text { Gapmer }\end{array}$} & 3 & $\begin{array}{c}\text { Intrathecal } \\
(120 \mathrm{mg})\end{array}$ & $\begin{array}{c}\text { Recruiting } \\
\text { (2019 2022) }\end{array}$ & NCT03761849 & $\begin{array}{l}\text { Hoffmann- } \\
\text { La Roche }\end{array}$ \\
\hline & & & $1 / 2$ & $\begin{array}{c}\text { Intrathecal } \\
(10,30,60,90 \\
\text { and } 120 \mathrm{mg})\end{array}$ & $\begin{array}{c}\text { Completed } \\
(2015-2017)\end{array}$ & NCT02519036 & $\begin{array}{c}\text { Ionis } \\
\text { Pharma. }\end{array}$ \\
\hline & WVE-120101 & - & & Intrathecal & & NCT03225846 & fe \\
\hline & WVE-120102 & Gapmer & $1 / 2$ & $\begin{array}{c}(2,4,8,16 \text { and } \\
32 \mathrm{mg})\end{array}$ & $(2017-2020)$ & NCT03225833 & Sciences \\
\hline
\end{tabular}




\section{COMPLIANCE WITH ETHICAL STANDARDS}

\section{CONFLICT OF INTEREST}

AV is an employee of SQY therapeutics, developing tcDNA-ASOs. AG and FB declare no conflict of interest.

\section{FUNDING}

Authors are supported by the Institut National de la santé et la recherche médicale (INSERM), the Association Monegasque contre les myopathies (AMM), the Duchenne Parent project France (DPPF) and the Fondation UVSQ. AV is an employee of SQY therapeutics.

\section{ACKNOLEDGEMENT}

This is a pre-print of an article published in Drugs. The final authenticated version is available online at: https://doi.org/10.1007/s40265-020-01363-

\section{REFERENCES}

1. Kaur, H, Wengel, J and Maiti, S (2007). LNA-modified oligonucleotides effectively drive intramolecular-stable hairpin to intermolecular-duplex state. Biochem. Biophys. Res. Commun. 352: 118-122.

2. Griepenburg, JC, Rapp, TL, Carroll, PJ, Eberwine, J and Dmochowski, IJ (2015). Ruthenium-Caged Antisense Morpholinos for Regulating Gene Expression in Zebrafish Embryos. Chem Sci 6: 23422346.

3. Gilar, M, Belenky, A, Smisek, DL, Bourque, A and Cohen, AS (1997). Kinetics of phosphorothioate oligonucleotide metabolism in biological fluids. Nucleic Acids Res. 25: 3615-3620.

4. Zamecnik, PC and Stephenson, ML (1978). Inhibition of Rous sarcoma virus replication and cell transformation by a specific oligodeoxynucleotide. Proc. Natl. Acad. Sci. U.S.A. 75: 280-284.

5. Schoch, KM and Miller, TM (2017). Antisense Oligonucleotides: Translation from Mouse Models to Human Neurodegenerative Diseases. Neuron 94: 1056-1070.

6. Wickstrom, E (1986). Oligodeoxynucleotide stability in subcellular extracts and culture media. J. Biochem. Biophys. Methods 13: 97-102.

7. Wickstrom, E (1986). Oligodeoxynucleotide stability in subcellular extracts and culture media. J. Biochem. Biophys. Methods 13: 97-102.

8. Gaus, HJ, Gupta, R, Chappell, AE, Østergaard, ME, Swayze, EE and Seth, PP (2019). Characterization of the interactions of chemically-modified therapeutic nucleic acids with plasma proteins using a fluorescence polarization assay. Nucleic Acids Res. 47: 1110-1122.

9. Crooke, ST, Wang, S, Vickers, TA, Shen, W and Liang, X-H (2017). Cellular uptake and trafficking of antisense oligonucleotides. Nat. Biotechnol. 35: 230-237. 
10. Iannitti, T, Morales-Medina, JC and Palmieri, B (2014). Phosphorothioate oligonucleotides: effectiveness and toxicity. Curr Drug Targets 15: 663-673.

11. Crooke, ST, Baker, BF, Witztum, JL, Kwoh, TJ, Pham, NC, Salgado, N, et al. (2017). The Effects of 2'-O-Methoxyethyl Containing Antisense Oligonucleotides on Platelets in Human Clinical Trials. Nucleic Acid Ther 27: 121-129.

12. Senn, JJ, Burel, S and Henry, SP (2005). Non-CpG-containing antisense 2'-methoxyethyl oligonucleotides activate a proinflammatory response independent of Toll-like receptor 9 or myeloid differentiation factor 88. J. Pharmacol. Exp. Ther. 314: 972-979.

13. Henry, SP, Beattie, G, Yeh, G, Chappel, A, Giclas, P, Mortari, A, et al. (2002). Complement activation is responsible for acute toxicities in rhesus monkeys treated with a phosphorothioate oligodeoxynucleotide. Int. Immunopharmacol. 2: 1657-1666.

14. Iannitti, T, Morales-Medina, JC and Palmieri, B (2014). Phosphorothioate oligonucleotides: effectiveness and toxicity. Curr Drug Targets 15: 663-673.

15. Sheehan, JP and Phan, TM (2001). Phosphorothioate oligonucleotides inhibit the intrinsic tenase complex by an allosteric mechanism. Biochemistry 40: 4980-4989.

16. Eckstein, F (2014). Phosphorothioates, essential components of therapeutic oligonucleotides. Nucleic Acid Ther 24: 374-387.

17. Goyenvalle, A, Leumann, C and Garcia, L (2016). Therapeutic Potential of Tricyclo-DNA antisense oligonucleotides. J Neuromuscul Dis 3: 157-167.

18. Henry, S, Stecker, K, Brooks, D, Monteith, D, Conklin, B and Bennett, CF (2000). Chemically modified oligonucleotides exhibit decreased immune stimulation in mice. J. Pharmacol. Exp. Ther. 292: 468-479.

19. Summerton, J and Weller, D (1997). Morpholino antisense oligomers: design, preparation, and properties. Antisense Nucleic Acid Drug Dev. 7: 187-195.

20. Hagedorn, PH, Persson, R, Funder, ED, Albæk, N, Diemer, SL, Hansen, DJ, et al. (2017). Locked nucleic acid: modality, diversity, and drug discovery. Drug Discov.

Todaydoi:10.1016/j.drudis.2017.09.018.

21. Seth, PP, Siwkowski, A, Allerson, CR, Vasquez, G, Lee, S, Prakash, TP, et al. (2008). Design, synthesis and evaluation of constrained methoxyethyl (CMOE) and constrained ethyl (cEt) nucleoside analogs. Nucleic Acids Symp Ser (Oxf): 553-554doi:10.1093/nass/nrn280.

22. Gupta, A, Mishra, A and Puri, N (2017). Peptide nucleic acids: Advanced tools for biomedical applications. J. Biotechnol. 259: 148-159.

23. Crooke, ST, Witztum, JL, Bennett, CF and Baker, BF (2019). RNA-Targeted Therapeutics. Cell Metab. 29: 501.

24. Bennett, CF (2019). Therapeutic Antisense Oligonucleotides Are Coming of Age. Annu. Rev. Med. 70: 307-321.

25. Crooke, ST (2017). Molecular Mechanisms of Antisense Oligonucleotides. Nucleic Acid Therapeutics 27: 70-77.

26. Godfrey, C, Desviat, LR, Smedsrød, B, Piétri-Rouxel, F, Denti, MA, Disterer, P, et al. (2017). Delivery is key: lessons learnt from developing splice-switching antisense therapies. $E M B O M O I$ Med 9: 545-557.

27. Mah, JK, Korngut, L, Dykeman, J, Day, L, Pringsheim, T and Jette, N (2014). A systematic review and meta-analysis on the epidemiology of Duchenne and Becker muscular dystrophy. Neuromuscul. Disord. 24: 482-491.

28. Arechavala-Gomeza, V, Kinali, M, Feng, L, Guglieri, M, Edge, G, Main, M, et al. (2010). Revertant fibres and dystrophin traces in Duchenne muscular dystrophy: implication for clinical trials. Neuromuscul. Disord. 20: 295-301.

29. Lu, QL, Morris, GE, Wilton, SD, Ly, T, Artem'yeva, OV, Strong, P, et al. (2000). Massive idiosyncratic exon skipping corrects the nonsense mutation in dystrophic mouse muscle and produces functional revertant fibers by clonal expansion. J Cell Biol 148: 985-96. 
32. Aartsma-Rus, A, Fokkema, I, Verschuuren, J, Ginjaar, I, van Deutekom, J, van Ommen, GJ, et al. (2009). Theoretic applicability of antisense-mediated exon skipping for Duchenne muscular dystrophy mutations. Hum Mutat 30: 293-9.

33. Takeshima, Y, Yagi, M, Wada, H, Ishibashi, K, Nishiyama, A, Kakumoto, M, et al. (2006). Intravenous infusion of an antisense oligonucleotide results in exon skipping in muscle dystrophin mRNA of Duchenne muscular dystrophy. Pediatr Res 59: 690-4.

34. Lu, QL, Mann, CJ, Lou, F, Bou-Gharios, G, Morris, GE, Xue, SA, et al. (2003). Functional amounts of dystrophin produced by skipping the mutated exon in the mdx dystrophic mouse. Nat Med 9: 1009-14.

35. Van Deutekom, JC, Janson, AA, Ginjaar, IB, Frankhuizen, WS, Aartsma-Rus, A, Bremmer-Bout, $M$, et al. (2007). Local dystrophin restoration with antisense oligonucleotide PRO051. New England Journal of Medicine 357: 2677-2686.

36. Goemans, NM, Tulinius, M, van den Akker, JT, Burm, BE, Ekhart, PF, Heuvelmans, N, et al. (2011). Systemic administration of PRO051 in Duchenne's muscular dystrophy. New England Journal of Medicine 364: 1513-1522.

37. Goemans, NM, Tulinius, M, van den Hauwe, M, Kroksmark, A-K, Buyse, G, Wilson, RJ, et al. (2016). Long-Term Efficacy, Safety, and Pharmacokinetics of Drisapersen in Duchenne Muscular Dystrophy: Results from an Open-Label Extension Study. PloS one 11: e0161955.

38. Goemans, N, Mercuri, E, Belousova, E, Komaki, H, Dubrovsky, A, McDonald, CM, et al. (2018). A randomized placebo-controlled phase 3 trial of an antisense oligonucleotide, drisapersen, in Duchenne muscular dystrophy. Neuromuscul. Disord. 28: 4-15.

39. Alter, J, Lou, F, Rabinowitz, A, Yin, H, Rosenfeld, J, Wilton, SD, et al. (2006). Systemic delivery of morpholino oligonucleotide restores dystrophin expression bodywide and improves dystrophic pathology. Nat Med 12: 175-7.

40. Kinali, M, Arechavala-Gomeza, V, Feng, L, Cirak, S, Hunt, D, Adkin, C, et al. (2009). Local restoration of dystrophin expression with the morpholino oligomer AVI-4658 in Duchenne muscular dystrophy: a single-blind, placebo-controlled, dose-escalation, proof-of-concept study. Lancet Neurol 8: 918-28.

41. Cirak, S, Arechavala-Gomeza, V, Guglieri, M, Feng, L, Torelli, S, Anthony, K, et al. (2011). Exon skipping and dystrophin restoration in patients with Duchenne muscular dystrophy after systemic phosphorodiamidate morpholino oligomer treatment: an open-label, phase 2, dose-escalation study. Lancet 378: 595-605.

42. Mendell, JR, Rodino-Klapac, LR, Sahenk, Z, Roush, K, Bird, L, Lowes, LP, et al. (2013). Eteplirsen for the treatment of Duchenne muscular dystrophy: Eteplirsen for DMD. Annals of Neurology 74: 637-647.

43. Mendell, JR, Goemans, N, Lowes, LP, Alfano, LN, Berry, K, Shao, J, et al. (2016). Longitudinal effect of eteplirsen versus historical control on ambulation in Duchenne muscular dystrophy: Eteplirsen in DMD. Annals of Neurology 79: 257-271.

44. Aartsma-Rus, A and Goemans, N (2019). A Sequel to the Eteplirsen Saga: Eteplirsen Is Approved in the United States but Was Not Approved in Europe. Nucleic Acid Ther 29: 13-15.

45. Alfano, LN, Charleston, JS, Connolly, AM, Cripe, L, Donoghue, C, Dracker, R, et al. (2019). Long-term treatment with eteplirsen in nonambulatory patients with Duchenne muscular dystrophy. Medicine (Baltimore) 98: e15858.

46. Carver, MP, Charleston, JS, Shanks, C, Zhang, J, Mense, M, Sharma, AK, et al. (2016). Toxicological Characterization of Exon Skipping Phosphorodiamidate Morpholino Oligomers (PMOs) in Non-human Primates. J Neuromuscul Dis 3: 381-393.

47. Frank, DE, Schnell, FJ, Akana, C, El-Husayni, SH, Desjardins, CA, Morgan, J, et al. (2020). Increased dystrophin production with golodirsen in patients with Duchenne muscular dystrophy. Neurology 94: e2270-e2282.

48. Heo, Y-A (2020). Golodirsen: First Approval. Drugs 80: 329-333. 
49. Komaki, H, Nagata, T, Saito, T, Masuda, S, Takeshita, E, Sasaki, M, et al. (2018). Systemic administration of the antisense oligonucleotide NS-065/NCNP-01 for skipping of exon 53 in patients with Duchenne muscular dystrophy. Sci Trans/ Med 10.

50. Roshmi, RR and Yokota, T (2019). Viltolarsen for the treatment of Duchenne muscular dystrophy. Drugs Today 55: 627-639.

51. Aartsma-Rus, A, Morgan, J, Lonkar, P, Neubert, H, Owens, J, Binks, M, et al. (2019). Report of a TREAT-NMD/World Duchenne Organisation Meeting on Dystrophin Quantification Methodology. J Neuromuscul Dis 6: 147-159.

52. (2020). Wave Life Sciences Announces Suvodirsen Phase 1 Safety and Tolerability Data and Phase 2/3 Clinical Trial Design. Wave Life Sciencesat <https://ir.wavelifesciences.com/newsreleases/news-release-details/wave-life-sciences-announces-suvodirsen-phase-1-safety-and>.

54. Lee, T, Awano, H, Yagi, M, Matsumoto, M, Watanabe, N, Goda, R, et al. (2017). 2'-O-Methyl RNA/Ethylene-Bridged Nucleic Acid Chimera Antisense Oligonucleotides to Induce Dystrophin Exon 45 Skipping. Genes (Basel) 8.

55. DAIICHI SANKYO COMPANY (2018). Daiichi Sankyo Announces Phase 1/2 Clinical Trial Results for DS-5141 (Therapeutic Agent for Duchenne Muscular Dystrophy) in Japanat $<$ https://www.daiichisankyo.com/media_investors/media_relations/press_releases/detail/00684 0.html>.

56. Gait, MJ, Arzumanov, AA, McClorey, G, Godfrey, C, Betts, C, Hammond, S, et al. (2019). CellPenetrating Peptide Conjugates of Steric Blocking Oligonucleotides as Therapeutics for Neuromuscular Diseases from a Historical Perspective to Current Prospects of Treatment. Nucleic Acid Ther 29: 1-12.

57. Moulton, HM and Moulton, JD. Morpholinos and their peptide conjugates: Therapeutic promise and challenge for Duchenne muscular dystrophy. Biochim Biophys Actaat $<$ http://www.ncbi.nlm.nih.gov/entrez/query.fcgi?cmd=Retrieve\&db=PubMed\&dopt=Citation\&list _uids $=20170628>$.

58. Goyenvalle, A, Griffith, G, Babbs, A, El Andaloussi, S, Ezzat, K, Avril, A, et al. (2015). Functional correction in mouse models of muscular dystrophy using exon-skipping tricyclo-DNA oligomers. Nature medicine 21: 270-5.

59. Relizani, K, Griffith, G, Echevarría, L, Zarrouki, F, Facchinetti, P, Vaillend, C, et al. (2017). Efficacy and Safety Profile of Tricyclo-DNA Antisense Oligonucleotides in Duchenne Muscular Dystrophy Mouse Model. Mol Ther Nucleic Acids 8: 144-157.

60. Goyenvalle, A, Vulin, A, Fougerousse, F, Leturcq, F, Kaplan, JC, Garcia, L, et al. (2004). Rescue of dystrophic muscle through U7 snRNA-mediated exon skipping. Science 306: 1796-9.

61. Vulin, A, Barthelemy, I, Goyenvalle, A, Thibaud, JL, Beley, C, Griffith, G, et al. (2012). Muscle function recovery in golden retriever muscular dystrophy after AAV1-U7 exon skipping. Mol Ther 20: 2120-33.

62. Wein, N, Vulin, A, Falzarano, MS, Szigyarto, CA-K, Maiti, B, Findlay, A, et al. (2014). Translation from a DMD exon 5 IRES results in a functional dystrophin isoform that attenuates dystrophinopathy in humans and mice. Nat. Med. 20: 992-1000.

63. Verhaart, IEC, Robertson, A, Wilson, IJ, Aartsma-Rus, A, Cameron, S, Jones, CC, et al. (2017). Prevalence, incidence and carrier frequency of $5 q$-linked spinal muscular atrophy - a literature review. Orphanet J Rare Dis 12: 124.

64. Calucho, M, Bernal, S, Alías, L, March, F, Venceslá, A, Rodríguez-Álvarez, FJ, et al. (2018). Correlation between SMA type and SMN2 copy number revisited: An analysis of 625 unrelated Spanish patients and a compilation of 2834 reported cases. Neuromuscul. Disord. 28: 208-215. 65. Scholl, R, Marquis, J, Meyer, K and Schümperli, D (2007). Spinal muscular atrophy: position and functional importance of the branch site preceding SMN exon 7. RNA Biol 4: 34-37.

66. Singh, RN and Singh, NN (2018). Mechanism of Splicing Regulation of Spinal Muscular Atrophy Genes. Adv Neurobiol 20: 31-61. 
67. Singh, NK, Singh, NN, Androphy, EJ and Singh, RN (2006). Splicing of a Critical Exon of Human Survival Motor Neuron Is Regulated by a Unique Silencer Element Located in the Last Intron. Molecular and Cellular Biology 26: 1333-1346.

68. Hua, Y, Sahashi, K, Hung, G, Rigo, F, Passini, MA, Bennett, CF, et al. (2010). Antisense correction of SMN2 splicing in the CNS rescues necrosis in a type III SMA mouse model. Genes Dev 24: $1634-1644$.

69. Hua, Y, Sahashi, K, Rigo, F, Hung, G, Horev, G, Bennett, CF, et al. (2011). Peripheral SMN restoration is essential for long-term rescue of a severe SMA mouse model. Nature 478: 123-126.

70. Chiriboga, CA, Swoboda, KJ, Darras, BT, lannaccone, ST, Montes, J, De Vivo, DC, et al. (2016). Results from a phase 1 study of nusinersen (ISIS-SMNRx) in children with spinal muscular atrophy. Neurology 86: 890-897.

71. Finkel, RS, Chiriboga, CA, Vajsar, J, Day, JW, Montes, J, De Vivo, DC, et al. (2016). Treatment of infantile-onset spinal muscular atrophy with nusinersen: a phase 2 , open-label, dose-escalation study. Lancet 388: 3017-3026.

72. Nusinersen initiated in infants during the presymptomatic stage of spinal muscular atrophy: Interim efficacy and safety results from the Phase 2 NURTURE study - Neuromuscular Disordersat <https://www.nmd-journal.com/article/S0960-8966(19)31127-7/fulltext>.

73. Mercuri, E, Darras, BT, Chiriboga, CA, Day, JW, Campbell, C, Connolly, AM, et al. (2018). Nusinersen versus Sham Control in Later-Onset Spinal Muscular Atrophy. New England Journal of Medicine 378: 625-635.

74. Darras, BT, Chiriboga, CA, lannaccone, ST, Swoboda, KJ, Montes, J, Mignon, L, et al. (2019). Nusinersen in later-onset spinal muscular atrophy: Long-term results from the phase $1 / 2$ studies. Neurology 92: e2492-e2506.

75. Meylemans, A and De Bleecker, J (2019). Current evidence for treatment with nusinersen for spinal muscular atrophy: a systematic review. Acta Neurol Belg 119: 523-533.

76. Shababi, M, Lorson, CL and Rudnik-Schöneborn, SS (2014). Spinal muscular atrophy: a motor neuron disorder or a multi-organ disease? J. Anat. 224: 15-28.

77. Bortolani, S, Stura, G, Ventilii, G, Vercelli, L, Rolle, E, Ricci, F, et al. (2019). Intrathecal administration of nusinersen in adult and adolescent patients with spinal muscular atrophy and scoliosis: Transforaminal versus conventional approach. Neuromuscul. Disord. 29: 742-746.

78. Cordts, I, Lingor, P, Friedrich, B, Pernpeintner, V, Zimmer, C, Deschauer, M, et al. (2020). Intrathecal nusinersen administration in adult spinal muscular atrophy patients with complex spinal anatomy. Ther Adv Neurol Disord 13.

79. Strauss, KA, Carson, VJ, Brigatti, KW, Young, M, Robinson, DL, Hendrickson, C, et al. (2018). Preliminary Safety and Tolerability of a Novel Subcutaneous Intrathecal Catheter System for Repeated Outpatient Dosing of Nusinersen to Children and Adults With Spinal Muscular Atrophy. J Pediatr Orthop 38: e610-e617.

80. Hammond, SM, Hazell, G, Shabanpoor, F, Saleh, AF, Bowerman, M, Sleigh, JN, et al. (2016). Systemic peptide-mediated oligonucleotide therapy improves long-term survival in spinal muscular atrophy. Proc. Natl. Acad. Sci. U.S.A. 113: 10962-10967.

81. Robin, V, Griffith, G, Carter, J-PL, Leumann, CJ, Garcia, L and Goyenvalle, A (2017). Efficient SMN Rescue following Subcutaneous Tricyclo-DNA Antisense Oligonucleotide Treatment. Mol Ther Nucleic Acids 7: 81-89.

82. Ramdas, $S$ and Servais, L (2020). New treatments in spinal muscular atrophy: an overview of currently available data. Expert Opin Pharmacother 21: 307-315.

83. Harper, PS (2009). Myotonic dystrophy, Oxford University Press, Oxford ; New York, 106pp. 84. Overby, SJ, Cerro-Herreros, E, Llamusi, B and Artero, R (2018). RNA-mediated therapies in myotonic dystrophy. Drug Discov. Today 23: 2013-2022.

85. Wheeler, TM, Lueck, JD, Swanson, MS, Dirksen, RT and Thornton, CA (2007). Correction of CIC-1 splicing eliminates chloride channelopathy and myotonia in mouse models of myotonic dystrophy. Journal of Clinical Investigationdoi:10.1172/JCI33355. 
86. Wheeler, TM, Sobczak, K, Lueck, JD, Osborne, RJ, Lin, X, Dirksen, RT, et al. (2009). Reversal of RNA dominance by displacement of protein sequestered on triplet repeat RNA. Science 325: 3369.

87. Lee, JE, Bennett, CF and Cooper, TA (2012). RNase H-mediated degradation of toxic RNA in myotonic dystrophy type 1. Proc. Natl. Acad. Sci. U.S.A. 109: 4221-4226.

88. Wheeler, TM, Leger, AJ, Pandey, SK, MacLeod, AR, Nakamori, M, Cheng, SH, et al. (2012). Targeting nuclear RNA for in vivo correction of myotonic dystrophy. Nature 488: 111-115.

89. Seth, PP, Siwkowski, A, Allerson, CR, Vasquez, G, Lee, S, Prakash, TP, et al. (2009). Short antisense oligonucleotides with novel $2^{\prime}-4$ ' conformationaly restricted nucleoside analogues show improved potency without increased toxicity in animals. J. Med. Chem. 52: 10-13.

90. Pandey, SK, Wheeler, TM, Justice, SL, Kim, A, Younis, HS, Gattis, D, et al. (2015). Identification and Characterization of Modified Antisense Oligonucleotides Targeting DMPK in Mice and Nonhuman Primates for the Treatment of Myotonic Dystrophy Type 1. Journal of Pharmacology and Experimental Therapeutics 355: 310-321.

91. Jauvin, D, Chrétien, J, Pandey, SK, Martineau, L, Revillod, L, Bassez, G, et al. (2017). Targeting DMPK with Antisense Oligonucleotide Improves Muscle Strength in Myotonic Dystrophy Type 1 Mice. Mol Ther Nucleic Acids 7: 465-474.

92. González-Barriga, A, Kranzen, J, Croes, HJE, Bijl, S, van den Broek, WJAA, van Kessel, IDG, et al. (2015). Cell membrane integrity in myotonic dystrophy type 1: implications for therapy. PLoS ONE 10: e0121556.

93. Prakash, TP, Mullick, AE, Lee, RG, Yu, J, Yeh, ST, Low, A, et al. (2019). Fatty acid conjugation enhances potency of antisense oligonucleotides in muscle. Nucleic Acids Res. 47: 6029-6044.

94. Østergaard, ME, Jackson, M, Low, A, E Chappell, A, G Lee, R, Peralta, RQ, et al. (2019). Conjugation of hydrophobic moieties enhances potency of antisense oligonucleotides in the muscle of rodents and non-human primates. Nucleic Acids Res. 47: 6045-6058.

95. Klein, AF, Varela, MA, Arandel, L, Holland, A, Naouar, N, Arzumanov, A, et al. (2019). Peptideconjugated oligonucleotides evoke long-lasting myotonic dystrophy correction in patient-derived cells and mice. J. Clin. Invest. 129: 4739-4744.

96. Talbott, EO, Malek, AM and Lacomis, D (2016). The epidemiology of amyotrophic lateral sclerosis. Handb Clin Neurol 138: 225-238.

97. Brown, RH and Al-Chalabi, A (2017). Amyotrophic Lateral Sclerosis. N. Engl. J. Med. 377: 162172.

98. Hardiman, O, Al-Chalabi, A, Chio, A, Corr, EM, Logroscino, G, Robberecht, W, et al. (2017). Amyotrophic lateral sclerosis. Nat Rev Dis Primers 3: 17071.

99. Andersen, PM and Al-Chalabi, A (2011). Clinical genetics of amyotrophic lateral sclerosis: what do we really know? Nat Rev Neurol 7: 603-615.

100. Rothstein, JD (2009). Current hypotheses for the underlying biology of amyotrophic lateral sclerosis. Ann. Neurol. 65 Suppl 1: S3-9.

101. Smith, RA, Miller, TM, Yamanaka, K, Monia, BP, Condon, TP, Hung, G, et al. (2006). Antisense oligonucleotide therapy for neurodegenerative disease. J. Clin. Invest. 116: 2290-2296.

102. Miller, TM, Pestronk, A, David, W, Rothstein, J, Simpson, E, Appel, SH, et al. (2013). An antisense oligonucleotide against SOD1 delivered intrathecally for patients with SOD1 familial amyotrophic lateral sclerosis: a phase 1, randomised, first-in-man study. Lancet Neurol 12: 435442.

103. McCampbell, A, Cole, T, Wegener, AJ, Tomassy, GS, Setnicka, A, Farley, BJ, et al. (2018). Antisense oligonucleotides extend survival and reverse decrement in muscle response in ALS models. J. Clin. Invest. 128: 3558-3567.

104. Cudkowicz, ME, McKenna-Yasek, D, Sapp, PE, Chin, W, Geller, B, Hayden, DL, et al. (1997). Epidemiology of mutations in superoxide dismutase in amyotrophic lateral sclerosis. Ann. Neurol. 41: $210-221$. 
105. Bennett, CF, Krainer, AR and Cleveland, DW (2019). Antisense Oligonucleotide Therapies for Neurodegenerative Diseases. Annu. Rev. Neurosci. 42: 385-406.

106. Berth, SH and Lloyd, TE (2019). How can an understanding of the C9orf72 gene translate into amyotrophic lateral sclerosis therapies? Expert Review of Neurotherapeutics 19: 895-897.

107. Jiang, J and Ravits, J (2019). Pathogenic Mechanisms and Therapy Development for C9orf72 Amyotrophic Lateral Sclerosis/Frontotemporal Dementia. Neurotherapeutics 16: 1115-1132.

108. Cammack, AJ, Atassi, N, Hyman, T, van den Berg, LH, Harms, M, Baloh, RH, et al. (2019). Prospective natural history study of C9orf72 ALS clinical characteristics and biomarkers. Neurology 93: e1605-e1617.

109. Jiang, J, Zhu, Q, Gendron, TF, Saberi, S, McAlonis-Downes, M, Seelman, A, et al. (2016). Gain of Toxicity from ALS/FTD-Linked Repeat Expansions in C9ORF72 Is Alleviated by Antisense Oligonucleotides Targeting GGGGCC-Containing RNAs. Neuron 90: 535-550.

110. Building a Neuromuscular Franchise: Progress in ALS. Biogen (June 5, 2019)at <https://investors.biogen.com/static-files/c21d50af-43ce-43a3-8e02-9fbd4a7c5558>.

111. Klim, JR, Vance, C and Scotter, EL (2019). Antisense oligonucleotide therapies for Amyotrophic Lateral Sclerosis: Existing and emerging targets. Int. J. Biochem. Cell Biol. 110: 149153.

112. Ishigaki, S and Sobue, G (2018). Importance of Functional Loss of FUS in FTLD/ALS. Front Mol Biosci 5: 44.

113. Marangi, G and Traynor, BJ (2015). Genetic causes of amyotrophic lateral sclerosis: new genetic analysis methodologies entailing new opportunities and challenges. Brain Res. 1607: 7593.

114. Zhou, Y, Liu, S, Liu, G, Öztürk, A and Hicks, GG (2013). ALS-Associated FUS Mutations Result in Compromised FUS Alternative Splicing and Autoregulation. PLoS Genet 9.

115. Sproviero, W, Shatunov, A, Stahl, D, Shoai, M, van Rheenen, W, Jones, AR, et al. (2017). ATXN2 trinucleotide repeat length correlates with risk of ALS. Neurobiol. Aging 51: 178.e1-178.e9.

116. Scoles, DR, Meera, P, Schneider, MD, Paul, S, Dansithong, W, Figueroa, KP, et al. (2017). Antisense oligonucleotide therapy for spinocerebellar ataxia type 2. Nature 544: 362-366.

117. Becker, LA, Huang, B, Bieri, G, Ma, R, Knowles, DA, Jafar-Nejad, P, et al. (2017). Therapeutic reduction of ataxin-2 extends lifespan and reduces pathology in TDP-43 mice. Nature 544: 367371.

118. Zhang, K and Rothstein, JD (2017). Neurodegenerative disease: Two-for-one on potential therapies. Nature 544: 302-303.

119. Neumann, M, Sampathu, DM, Kwong, LK, Truax, AC, Micsenyi, MC, Chou, TT, et al. (2006). Ubiquitinated TDP-43 in frontotemporal lobar degeneration and amyotrophic lateral sclerosis. Science 314: 130-133.

120. Ito, D and Suzuki, N (2011). Conjoint pathologic cascades mediated by ALS/FTLD-U linked RNA-binding proteins TDP-43 and FUS. Neurology 77: 1636-1643.

121. Kordasiewicz, HB, Stanek, LM, Wancewicz, EV, Mazur, C, McAlonis, MM, Pytel, KA, et al. (2012). Sustained therapeutic reversal of Huntington's disease by transient repression of huntingtin synthesis. Neuron 74: 1031-1044.

122. Martin, DDO, Kay, C, Collins, JA, Nguyen, YT, Slama, RA and Hayden, MR (2018). A human huntingtin SNP alters post-translational modification and pathogenic proteolysis of the protein causing Huntington disease. Sci Rep 8: 8096.

123. Keiser, MS, Kordasiewicz, HB and McBride, JL (2016). Gene suppression strategies for dominantly inherited neurodegenerative diseases: lessons from Huntington's disease and spinocerebellar ataxia. Hum. Mol. Genet. 25: R53-64.

124. Tabrizi, SJ, Leavitt, BR, Landwehrmeyer, GB, Wild, EJ, Saft, C, Barker, RA, et al. (2019). Targeting Huntingtin Expression in Patients with Huntington's Disease. N. Engl. J. Med. 380: 23072316. 
125. Rodrigues, FB and Wild, EJ (2018). Huntington's Disease Clinical Trials Corner: February 2018. $J$ Huntingtons Dis 7: 89-98.

126. Rodrigues, FB, Quinn, L and Wild, EJ (2019). Huntington's Disease Clinical Trials Corner: January 2019. J Huntingtons Dis 8: 115-125.

127. Evers, MM, Pepers, BA, van Deutekom, JCT, Mulders, SAM, den Dunnen, JT, Aartsma-Rus, A, et al. (2011). Targeting several CAG expansion diseases by a single antisense oligonucleotide. PLoS ONE 6: e24308.

128. Datson, NA, González-Barriga, A, Kourkouta, E, Weij, R, van de Giessen, J, Mulders, S, et al. (2017). The expanded CAG repeat in the huntingtin gene as target for therapeutic RNA modulation throughout the HD mouse brain. PLoS One 12.

129. Kay, C, Collins, JA, Skotte, NH, Southwell, AL, Warby, SC, Caron, NS, et al. (2015). Huntingtin Haplotypes Provide Prioritized Target Panels for Allele-specific Silencing in Huntington Disease Patients of European Ancestry. Mol. Ther. 23: 1759-1771.

130. Carroll, JB, Warby, SC, Southwell, AL, Doty, CN, Greenlee, S, Skotte, N, et al. (2011). Potent and Selective Antisense Oligonucleotides Targeting Single-Nucleotide Polymorphisms in the Huntington Disease Gene / Allele-Specific Silencing of Mutant Huntingtin. Mol Ther 19: 21782185.

131. Skotte, NH, Southwell, AL, Østergaard, ME, Carroll, JB, Warby, SC, Doty, CN, et al. (2014). Allele-Specific Suppression of Mutant Huntingtin Using Antisense Oligonucleotides: Providing a Therapeutic Option for All Huntington Disease Patients. In: Glorioso, JC (ed.). PLOS ONE 9: e107434.

132. Southwell, AL, Kordasiewicz, HB, Langbehn, D, Skotte, NH, Parsons, MP, Villanueva, EB, et al. (2018). Huntingtin suppression restores cognitive function in a mouse model of Huntington's disease. Sci Transl Med 10.

133. Unpacking Wave's PRECISION-HD2 huntingtin-lowering trial announcement - HDBuzz Huntington's disease research news.at <https://en.hdbuzz.net/277>.

134. Carroll, JB, Bates, GP, Steffan, J, Saft, C and Tabrizi, SJ (2015). Treating the whole body in Huntington's disease. Lancet Neurol 14: 1135-1142.

135. Neil, EE and Bisaccia, EK (2019). Nusinersen: A Novel Antisense Oligonucleotide for the Treatment of Spinal Muscular Atrophy. J Pediatr Pharmacol Ther 24: 194-203.

136. Joshua T. Cohen, James D. Chambers, Madison C. Silver, Pei-Jung Lin and Peter J. Neumann (2019). Putting The Costs And Benefits Of New Gene Therapies Into Perspectiveat <https://www.healthaffairs.org/do/10.1377/hblog20190827.553404/full/>.

137. Lee, BH, Collins, E, Lewis, L, Guntrum, D, Eichinger, K, Voter, K, et al. (2019). Combination therapy with nusinersen and AVXS-101 in SMA type 1. Neurology 93: 640-641.

138. Crudele, JM and Chamberlain, JS (2019). AAV-based gene therapies for the muscular dystrophies. Hum. Mol. Genet. 28: R102-R107.

139. Le Hir, M, Goyenvalle, A, Peccate, C, Précigout, G, Davies, KE, Voit, T, et al. (2013). AAV Genome Loss From Dystrophic Mouse Muscles During AAV-U7 snRNA-mediated Exon-skipping Therapy. Molecular Therapy 21: 1551-1558. 